\title{
Process Mineralogy Characteristics and Flotation Application of a Refractory Collophanite from Guizhou, China
}

\author{
Wei Xu ${ }^{1,2,3}$, Bo Shi ${ }^{1}$, Yan Tian ${ }^{3}$, Yue Chen ${ }^{3}$, Songqing $\mathrm{Li}^{2}$, Qian Cheng ${ }^{1}$ and Guangjun Mei ${ }^{1, *}$ \\ 1 School of Resources and Environmental Engineering, Wuhan University of Technology, Wuhan 430070, China; \\ gzu_xw@whut.edu.cn (W.X.); 293783@whut.edu.cn (B.S.); chengqian@whut.edu.cn (Q.C.) \\ 2 State Key Laboratory of Mineral Processing, Beijing 102628, China; lisongqing@bgrimm.com \\ 3 State Key Laboratory of Efficient Utilization for Low Grade Phosphate Rock and Its Associated Resources, \\ Guiyang 550002, China; tianyan@wengfu.com (Y.T.); chenyue@wengfu.com (Y.C.) \\ * Correspondence: meiguangjun@whut.edu.cn
}

Citation: Xu, W.; Shi, B.; Tian, Y.; Chen, Y.; Li, S.; Cheng, Q.; Mei, G. Process Mineralogy Characteristics and Flotation Application of a Refractory Collophanite from Guizhou, China. Minerals 2021, 11, 1249. https://doi.org/10.3390/ $\min 11111249$

Academic Editor: Mark I. Pownceby

Received: 16 October 2021

Accepted: 8 November 2021

Published: 10 November 2021

Publisher's Note: MDPI stays neutral with regard to jurisdictional claims in published maps and institutional affiliations.

Copyright: (c) 2021 by the authors. Licensee MDPI, Basel, Switzerland. This article is an open access article distributed under the terms and conditions of the Creative Commons Attribution (CC BY) license (https:/ / creativecommons.org/licenses/by/ $4.0 /)$.

\begin{abstract}
A refractory phosphate ore obtained from Guizhou, China, contains high amounts of detrimental metal impurities (e.g., Fe, $\mathrm{Al}$, and $\mathrm{Mg}$ ) which affect the deep wet processing of phosphorus products before use. In this study, mineralogy parameters of the ore such as mineral composition, disseminated particle size, mineral liberation degree, and intergrowth relationship were investigated using X-ray fluorescence spectrometer (XRF), X-ray powder diffractometer (XRD), and advanced mineral identification and characterization system (AMICS). The mechanism for flotation separation was also discussed. The results showed that the ore was a fine-grained calcareous-siliceous collophanite with high $\mathrm{P}_{2} \mathrm{O}_{5}$ grade. The gangue minerals such as quartz, sericite (muscovite), pyrite, and dolomite were finely disseminated and encapsulated by fluoroapatite particles in a rather complex relationship. A double reverse flotation process was carried out based on the separation principle of less flotation and more inhibition. A phosphorous concentrate with a $\mathrm{P}_{2} \mathrm{O}_{5}$ grade of $35.53 \%, \mathrm{SiO}_{2}$ content of $5.88 \%$, $\mathrm{MgO}$ content of $0.91 \%$, sesquioxide $\left(\mathrm{Fe}_{2} \mathrm{O}_{3}+\mathrm{Al}_{2} \mathrm{O}_{3}\right)$ content of $1.98 \%$, MER value of $8.13 \%$, and phosphorus recovery of $75.04 \%$ was obtained. Based on the flotation test results and the analysis of process mineralogy parameters, we concluded that the main causes of difficulty in separation of collophanite are fine disseminated particle size, poor mineral liberation degree, and serious argillization. The selection of foam-controlled collectors, efficient dispersing inhibitors and classified desliming process will be necessary for improving flotation index. These results provide a technical reference for subsequent development and utilization of collophanite resources.
\end{abstract}

Keywords: sedimentary collophanite; AMICS; sesquioxide; double reverse flotation; mechanism

\section{Introduction}

Phosphate ore is an essential raw material for manufacturing phosphoric acid, phosphate fertilizer, and other basic phosphorus products. It promotes national economic and social development and is irreplaceable and nonrenewable [1]. Presently, Guizhou contains 3.58 billion tons of phosphate rock, ranking third in China. Besides, Guizhou has more than $70 \%$ of sedimentary phosphorite, mainly complex and refractory calcareous-siliceous collophanite, characterized by various mineral impurities, complex structure, fine disseminated particle size, and difficult liberation [2,3]. During the wet process of phosphoric acid, $\mathrm{P}_{2} \mathrm{O}_{5}$ grade of phosphate ore should be greater than $29.0 \%$, the content of $\mathrm{MgO}$ and sesquioxide $\left(\mathrm{Fe}_{2} \mathrm{O}_{3}+\mathrm{Al}_{2} \mathrm{O}_{3}\right)$ should not exceed $1.0 \%$ and $2.5 \%$, respectively [4]. A high content of detrimental metal impurities $(\mathrm{Fe}, \mathrm{Al}$, and $\mathrm{Mg}$ ) in the ore can significantly impact the deep processing of downstream acid and fertilizer products.

Flotation is the most effective method for collophanite separation [5]. Presently, the research on the flotation process of calcareous-siliceous collophanite mainly focuses on the reagents, processes, and equipment of direct-reverse flotation and double reverse flotation, especially in the surface modification of mineral crystals, the combination of collectors, 
and the environmental regulation of pulp solution. The research results obtained enrich and develop the basic theory of flotation application [6]. As is well known, phosphate beneficiation is an engineering practice, and the implementation of the research should be in line with the production practice. However, most beneficiation practices can be conducted without fully identifying the process mineralogy characteristics, which is unsuitable for formulating the best beneficiation process and process optimization. The characteristics of "poor, fine, and miscellaneous" are common due to the continuous exploitation and utilization of phosphate mineral resources. It is difficult to concentrate calcareous-siliceous collophanite produced in different regions due to different mineral types, disseminated size, and co-associated relationships [7]. In recent years, several scientists have explained the complex flotation separation of minerals based on the process mineralogy, such as mineral granularity, mono-mineral liberation degree, and intergrowth relationship. For instance, Fang et al. [8] conducted a mineral quantitative liberation system (MLA) analysis on the floating products of a phosphate rock in Yunnan, China. They proposed three solutions that can improve quality and reduce impurity, providing theoretical basis for the process optimization of concentrators. Li et al. [9] also showed that more gangue minerals in the samples are disseminated in collophanite based on mineralogy research results, thus affecting the separation index. The results were verified through the flotation process test. Yang et al. [10] assessed the mono-mineral liberation degree of each product under different grinding fineness and verified the accuracy of the theoretical maximum recovery rate through a flotation test. The above results indicate that identifying key mineralogical parameters and process monitoring are essential for the efficient separation of complex and refractory ores. Besides, they are crucial in the process of mineral upgrading and impurity removal.

Herein, the advanced mineral identification and characterization system (AMICS) was used to conduct process mineralogy research on a refractory collophanite in Guizhou for the first time. The mineral composition was quantitatively analyzed. The disseminated mineral size, mono-mineral liberation, and intergrowth relationship were identified. The refractory mechanism of collophanite was analyzed based on the flotation process results and process mineralogy parameters. Therefore, this study provides theoretical guidance for the process optimization of other fine-grained calcareous-siliceous collophanite separation [11] and the application method of AMICS in the quantitative discussion of refractory mineral mechanism. Moreover, double reverse flotation under coarse grinding fineness, with superior product indexes, was realized. It fills the research gap that the ore cannot be beneficiated and utilized, and provides key basic data for the large-scale utilization of the ore resources.

\section{Materials and Methods}

\subsection{Ore Samples}

Collophanite $(200 \mathrm{~kg})$ was obtained from a mining enterprise in Guizhou, China. The ore was first crushed tounder $2 \mathrm{~mm}$ particle size using a sealed jaw crusher (model RK/PEX $-100 \times 125$, Wuhan Rock Grinding Equipment Co., Ltd., Wuhan, China) and a sealed double-roll crusher (model RK/PG $\$ 200 \times 75$, Wuhan Rock Grinding Equipment Co., Ltd., Wuhan, China). Then, with the grinding process using a three-roller and fourbarrel bar mill (model RK/BM, Wuhan Rock Grinding Equipment Co., Ltd., Wuhan, China), $63 \%$ of it was turned into a product under $75 \mu \mathrm{m}$. A small portion of the sample was ground to under $75 \mu \mathrm{m}$ particle size using vibration mills (model ZHM-1A, Beijing Zhonghe Technology Co., Ltd., Beijing, China) for X-ray fluorescence spectrometer (XRF) and X-ray powder diffractometer (XRD) detection. Some samples were wet-sieved into three particle size fractions $(+75 \mu \mathrm{m},-75+38 \mu \mathrm{m}$, and $-38 \mu \mathrm{m})$, then fully mixed and cured using epoxy resin and curing agent from Struers Corporation, Cleveland, $\mathrm{OH}, \mathrm{USA}$. The target sample was then polished using a metallographic sample polishing machine (model OU6310, Oupu Testing Instrument Co., Ltd., Cangzhou, China). An ion sputtering evaporation instrument (model ETD-2000C, Vision Precision Instruments, Beijing, China) 
was used to spray carbon on the polished target sample to ensure the conductivity of the sample surface, so as to meet the test requirements of AMICS.

\subsection{Reagents}

For anionic reverse flotation of carbonate minerals, industrial wastewater WFS ( $\mathrm{pH}$, 1-2) from Wengfu Group Chemical Company, Guizhou, China, was used as an acid inhibitor. WF-04, an industrial fatty acid soap, was used as the magnesium removal collector (Wengfu Group). WF-04 was prepared into an aqueous solution with a mass fraction of 1\%. Sodium carbonate (analytical reagent, BASF Chemical Co., Ltd., Tianjin, China) was used as a $\mathrm{pH}$ regulator for removing silicate minerals via cationic reverse flotation. Sodium carbonate was prepared into a $10 \%$ water solution. LH-01, a multi-formula system based on cationic quaternary ammonium salt from the independent research and development of Wengfu Group, was used as the collector for removing silicon and aluminum. It was prepared into an aqueous solution with a mass fraction of $1 \%$.

\subsection{Characterization Methods}

An X-ray fluorescence spectrometer (XRF) (model Axios ${ }^{\mathrm{mAX}}$, PANalytical B.V., Alemlo, The Netherlands) with a rhodium-anode tube was used for quantitative analysis of chemical elements at 4 kW. X-ray diffractometer (XRD) (model X'Pert3 Powder, PANalytical B.V., Alemlo, The Netherlands) with $\mathrm{Cu}$ target ceramic light tube was used for mineral phase identification with $2 \theta$ of $5-90^{\circ}$, voltage of $45 \mathrm{kV}$, and current of $40 \mathrm{~mA}$. A scanning electron microscope (SEM) (model EVO 15, Carl Zeiss Corporation, Oberkochen, Germany) and an X-ray energy dispersive spectrometer (model INCA X-act, Oxford Instruments Corporation, Abingdon, UK) were used to assess element distribution on the surface of feed materials and flotation products. The energy dispersive spectrum data was collected using Aztec software in NTS BSD mode at a multiple of 300. A polarizing microscope (model Axio Scope.A1, Carl Zeiss Corporation, Oberkochen, Germany) was used to identify the mineral phase of raw ore. The slice thickness of the rock for observation is $0.03 \mathrm{~mm}$. The mineralogical parameters, such as particle-phase composition, disseminated particle size, and liberation degree, were identified via AMICS (model Quanta 650, FEI Corporation, Hillsboro, OR, USA). AMICS mainly uses backscattered electron image and energy spectrum analysis to distinguish and identify different minerals [12]. The operation and image acquisition of the apparatus was controlled using SEM Control and AMICS Ivstigator software. The optimal operating distance and electron beam acceleration voltage were $10 \mathrm{~mm}$ and $25 \mathrm{kV}$, respectively. AMICS process software was used to process the test data.

\subsection{Flotation Tests}

Collophanite sample (150 g) was put into a single-cell flotation machine (model RK/FD III, Wuhan Rock Grinding Equipment Co., Ltd., Wuhan, China) with a capacity of $0.5 \mathrm{~L}$. Water was added to the pulp mass fraction of $25 \%$. The flotation machine speed and pulp temperature were set at $1900 \mathrm{r} / \mathrm{min}$ and $20^{\circ} \mathrm{C}$, respectively. In the magnesium removal stage, WFS was first added to adjust the pulp $\mathrm{pH}$ to 4.5 , and then $0.20 \mathrm{~kg} / \mathrm{t} \mathrm{WF-04}$ was added. The stirring and flotation durations were $2 \mathrm{~min}$ and $1 \mathrm{~min}$, respectively. In the desilication stage, sodium carbonate was first added to adjust the pulp pH to 7.0 (no further addition), and then LH-01 was added in five batches $(0.20 \mathrm{~kg} / \mathrm{t}$ in each addition). The reagent action and flotation durations were $2 \mathrm{~min}$. Flotation concentrate and tailings were dried, weighed, mixed, divided, sampled, and tested for grade of main elements. The yield and recovery were then calculated.

\section{Results and Discussion}

\subsection{Mineral Composition and Element Occurrence}

The chemical and mineral compositions of the collophanite are shown in Tables 1 and 2. The XRD diffraction results of the ore are shown in Figure 1.The SEM_EDS mapping analysis of the ore is shown in Figure 2.The distribution characteristics of the main mineral 
particles are shown in Figure 3. $\mathrm{P}_{2} \mathrm{O}_{5}$ grade was $29.40 \%, \omega(\mathrm{CaO}) / \omega\left(\mathrm{P}_{2} \mathrm{O}_{5}\right)$ was $1.43(>1.40)$, and $\mathrm{SiO}_{2}$ content was $13.37 \%$, indicating that the ore was a high-grade calcareous-siliceous collophanite. In the ore, $\mathrm{MgO}$ and sesquioxide $\left(\mathrm{Al}_{2} \mathrm{O}_{3}+\mathrm{Fe}_{2} \mathrm{O}_{3}\right)$ contents were $1.47 \%$ and $4.91 \%$, respectively. The MER $\left(\omega\left(\mathrm{MgO}+\mathrm{Al}_{2} \mathrm{O}_{3}+\mathrm{Fe}_{2} \mathrm{O}_{3}\right) / \omega\left(\mathrm{P}_{2} \mathrm{O}_{5}\right)\right)$ value was $21.70 \%$. The content of detrimental impurities in the ore was too high. The ore had a complex mineral composition, and the content of fluorapatite was as high as $79.76 \%$ (Figure 1 and Table 2). Gangue minerals contained silicate minerals (quartz, sericite (muscovite), kaolinite, etc.), carbonate minerals (dolomite, calcite), metal minerals (pyrite, limonite), and a small amount of barite, goyazite, chlorite, zircon, etc. Phosphorus was mainly found in fluorapatite and a small amount in goyazite. Silicate mainly occurred in quartz and sericite (muscovite). Aluminum mainly occurred in sericite (muscovite), kaolinite, and a small amount in goyazite. Magnesium mainly occurred in dolomite and sericite (muscovite). Iron mainly occurred in pyrite and limonite, and a small amount in sericite (muscovite). Fluoroapatite was the main target mineral in collophanite. The detrimental minerals in collophanite included quartz, sericite (muscovite), kaolinite, dolomite, and pyrite. Fluorapatite was the major mineral phase with uneven mineral particle size distribution and irregular particle shape (granular, block, strip structure, etc.) (Figure 3). The target minerals were closely associated with some gangue minerals and had significant inclusion characteristics. The reduction of MER value of the collophanite was achieved by removing carbonate and silicate gangue minerals. Flotation mainly removed silicate minerals (quartz, sericite (muscovite), kaolinite, etc.) as the ore had low $\mathrm{MgO}$ content, thus reducing the sesquioxide content in the ore.

Table 1. Chemical analyzes of collophanite with particle size of $-75 \mu \mathrm{m}$ detected by XRF.

\begin{tabular}{ccccccccc}
\hline Element & $\mathbf{P}_{\mathbf{2}} \mathbf{O}_{5}$ & $\mathbf{C a O}$ & $\mathbf{M g O}$ & $\mathbf{S i O}_{2}$ & $\mathbf{A l}_{\mathbf{2}} \mathbf{O}_{3}$ & $\mathbf{F e}_{\mathbf{2}} \mathbf{O}_{3}$ & $\mathbf{F}$ & $\mathbf{S O}_{3}$ \\
\hline Content (wt. \%) & 29.40 & 42.05 & 1.47 & 13.37 & 3.73 & 1.18 & 2.90 & 2.16 \\
\hline Element & $\mathrm{K}_{2} \mathrm{O}$ & $\mathrm{Na}_{2} \mathrm{O}$ & $\mathrm{BaO}$ & $\mathrm{ZrO}_{2}$ & $\mathrm{SrO}$ & $\mathrm{MnO}$ & LOI 1000 & \\
\hline Content (wt. \%) & 0.95 & 0.25 & 0.23 & 0.03 & 0.15 & 0.05 & 4.46 & \\
\hline
\end{tabular}

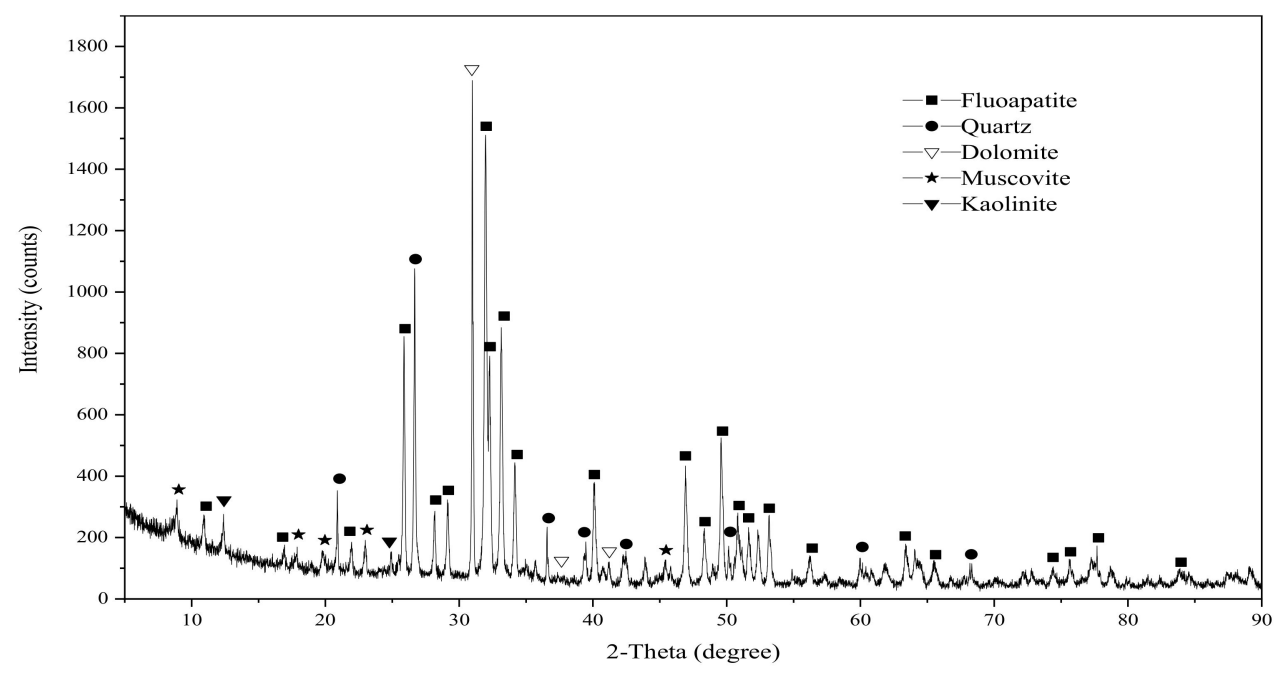

Figure 1. XRD spectra of collophanite with particle size of $-45 \mu \mathrm{m}$. 

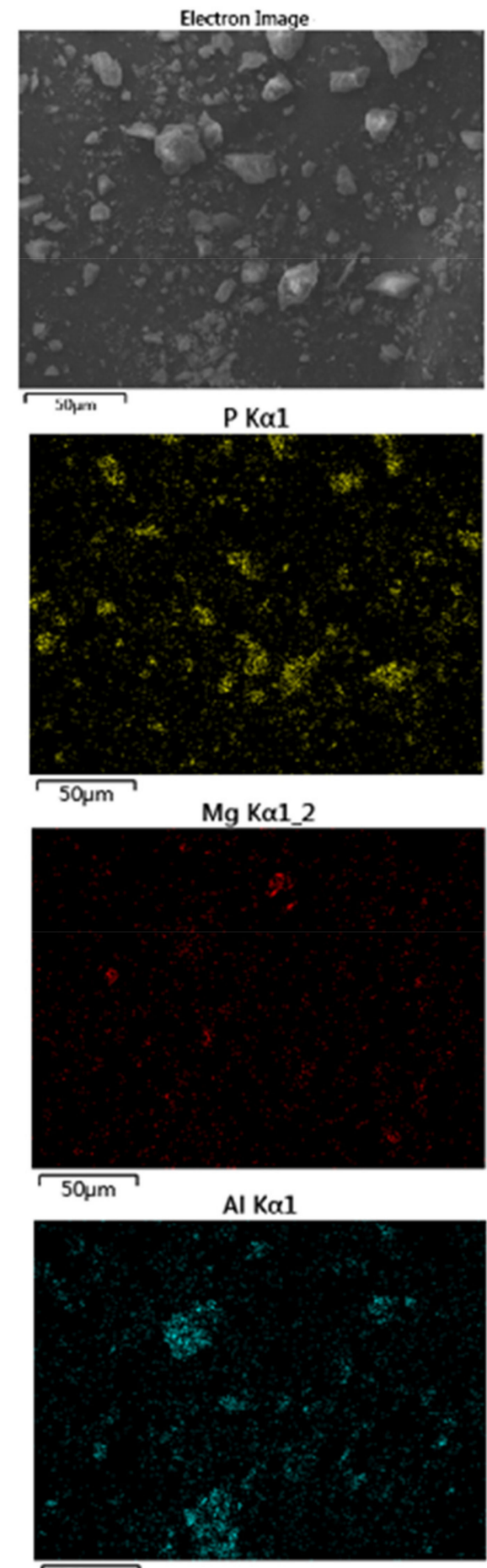

$\sqrt{50 \mu \mathrm{m}}$

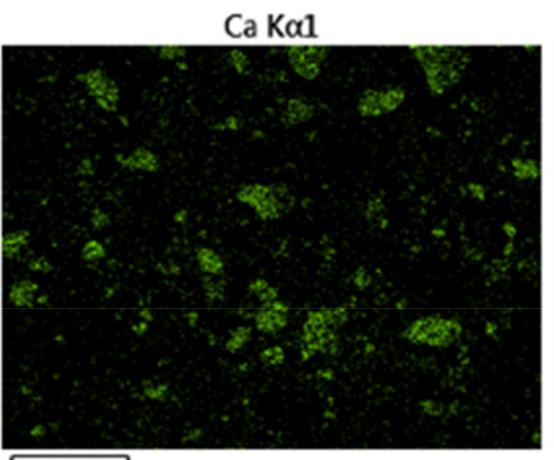

F K $\alpha 1 \_2$
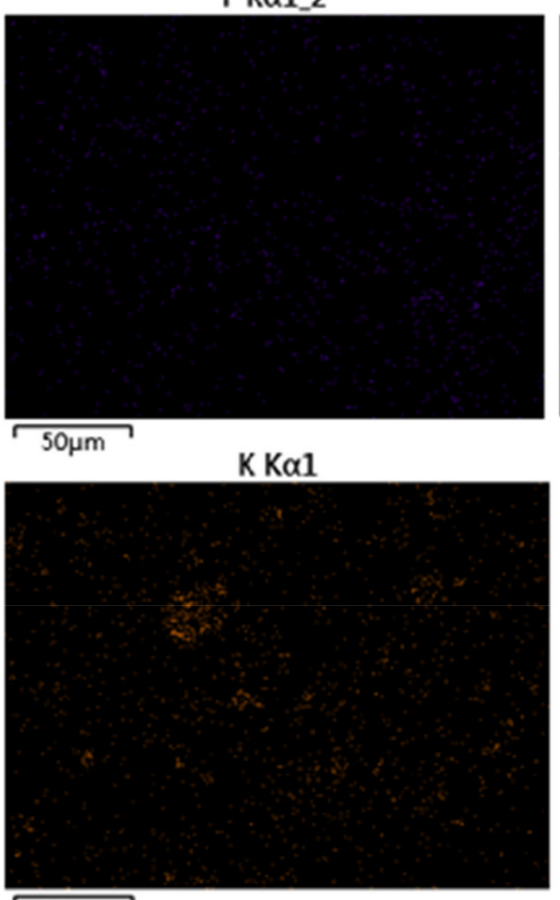

$\sqrt{50 \mu \mathrm{m}} \quad \mathrm{Fe} \mathrm{K} \alpha \mathbf{l}$

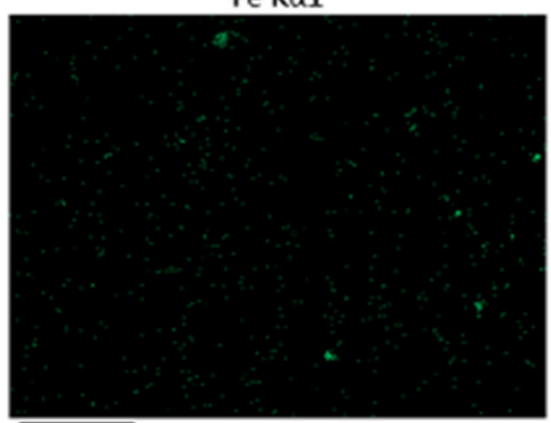

$\longdiv { 5 0 \mu m }$
Si K $\alpha 1$

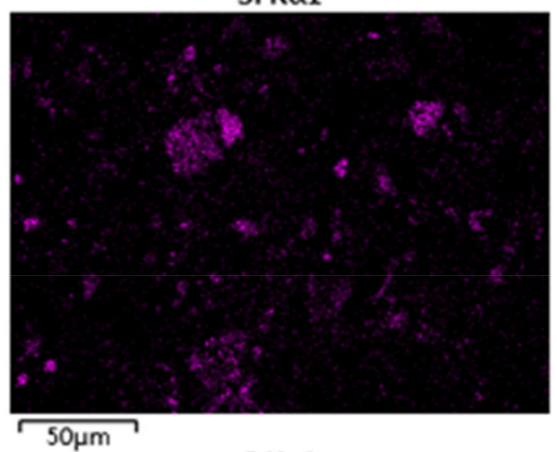

$S K \alpha 1$

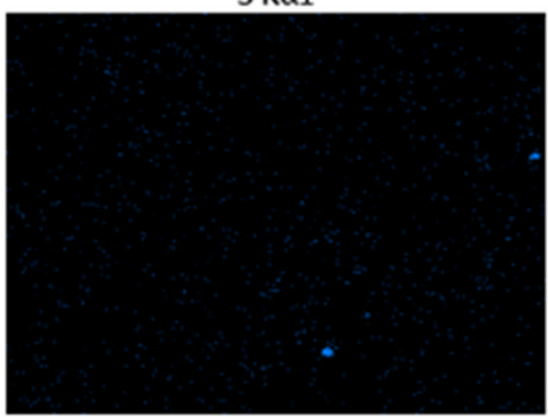

$\mathrm{O} \kappa \alpha 1$

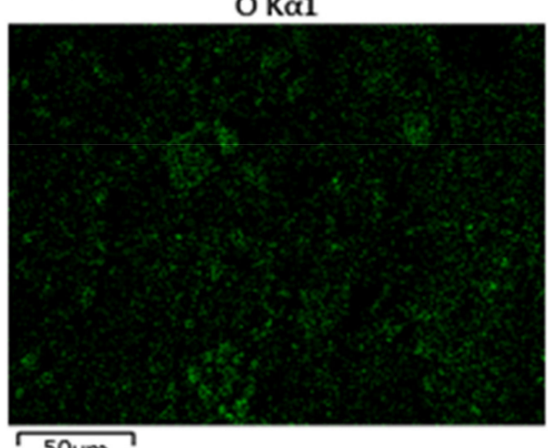

Figure 2. SEM-EDS elements mapping of collophanite with particle size of $-75 \mu \mathrm{m}$ accounting for $63 \%$.

Table 2. Mineral composition of collophanite with particle size of $-75 \mu \mathrm{m}$ accounting for $63 \%$ identified by AMICS.

\begin{tabular}{ccccccccc}
\hline Mineral & Fluorapatite & Quartz & $\begin{array}{c}\text { Sericite } \\
\text { (Muscovite) }\end{array}$ & Dolomite & Pyrite & Kaolinite & Limonite & Barite \\
\hline Content (wt. \%) & 79.76 & 7.17 & 5.18 & 4.02 & 1.53 & 1.04 & 0.48 & 0.29 \\
\hline Mineral & Rutile & Goyazite & Calcite & Ankerite & Chlorite & Zircon & Other \\
\hline Content (wt. \%) & 0.12 & 0.06 & 0.05 & 0.04 & 0.02 & 0.01 & 0.23 \\
\hline
\end{tabular}




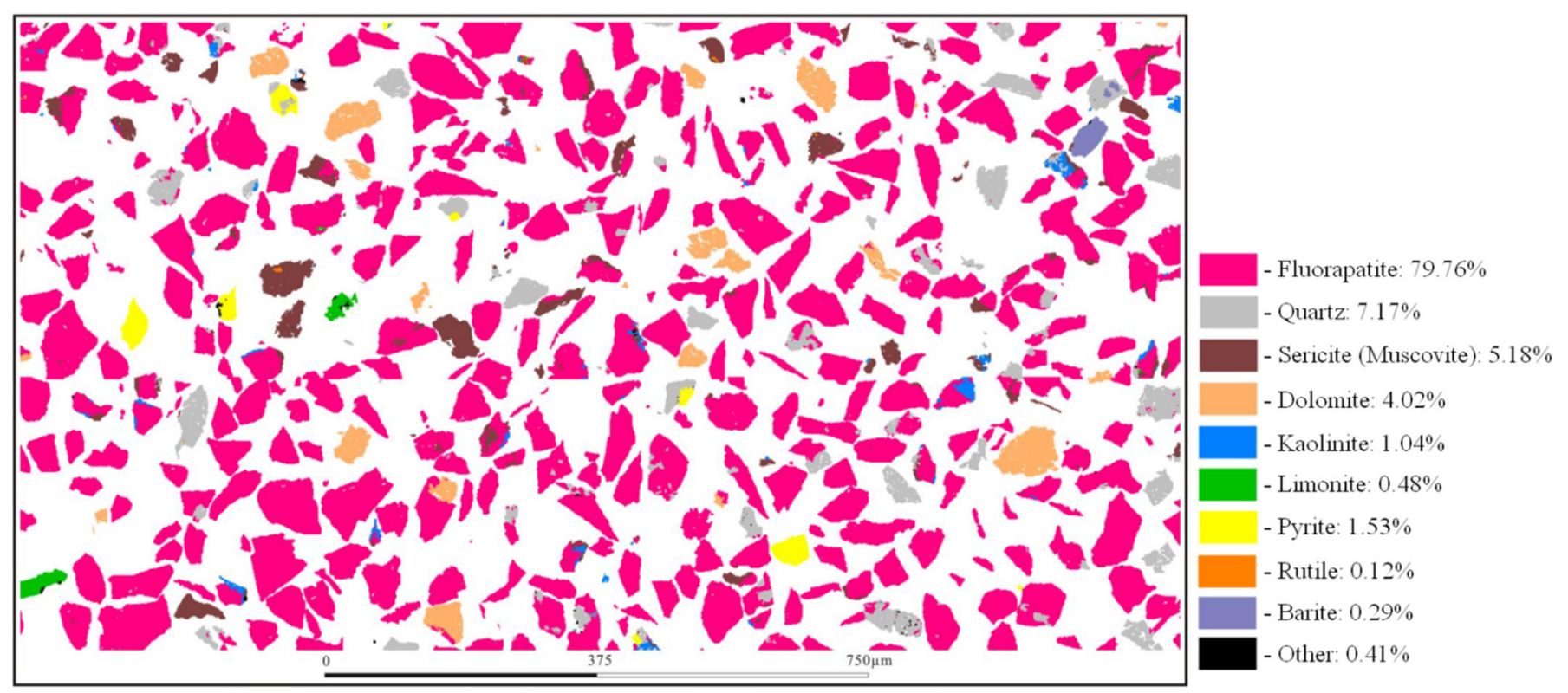

Figure 3. Particle phase diagram of collophanite with particle size of $-75 \mu \mathrm{m}$ accounting for $63 \%$ identified by AMICS.

\subsection{Disseminated Types and Liberation Characteristics of Fluorapatite}

Phosphorus in the ore mainly occurred in fluorapatite. There were two types of dissemination: granular (particle size of $0.005-0.19 \mathrm{~mm}$ ) and colloidal (less than $0.08 \mathrm{~mm}$ ). Granular was closely associated with gangue minerals, such as sericite (muscovite) and kaolinite. Fine-grained particles are part of the apatite wrapped in the gangue and are the main disseminated mode of apatite (Figure 4). Notably, some apatite also wrapped fine-grained quartz, kaolinite, and sericite (muscovite) (Figure 5). The particle size of these wrapped minerals was less than $0.04 \mathrm{~mm}$. This part of fluorapatite was not easy to liberate completely and separate, leading to the high content of $\mathrm{Al}$ and $\mathrm{Si}$ in collophanite flotation concentrate. Colloidal apatite was closely associated with quartz, etc., resembling a kind of stromatolite structure (Figure 6). This was rare with low content.

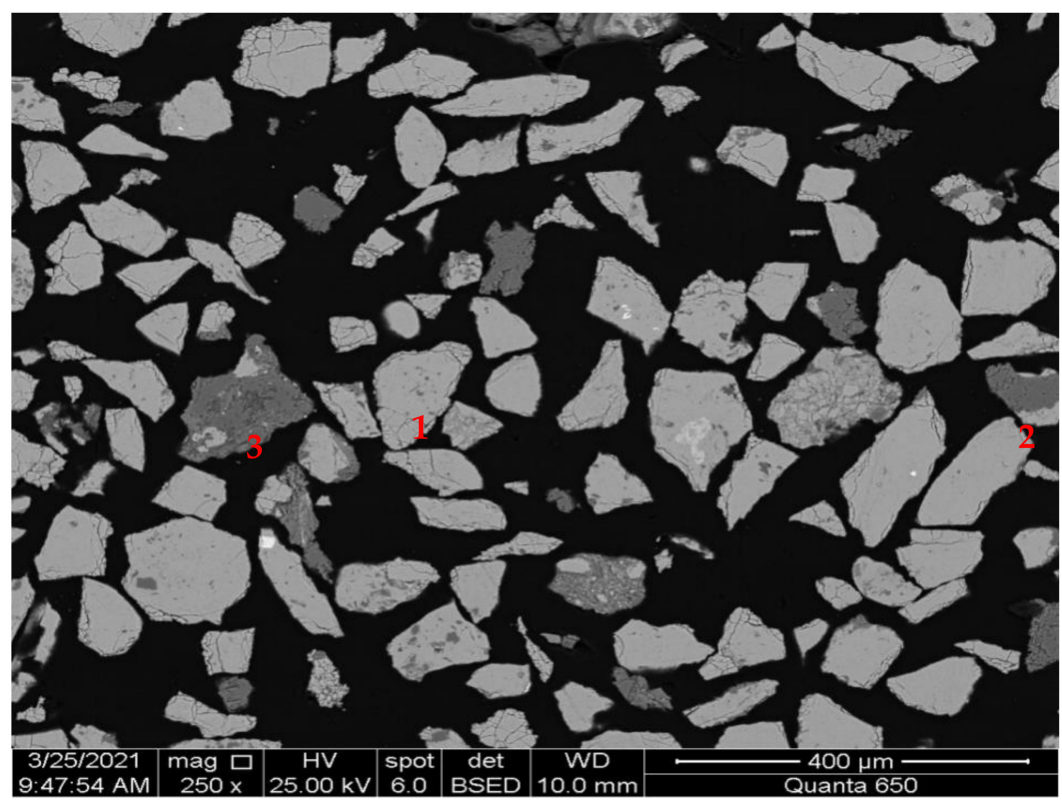

Figure 4. Main disseminated characteristics of apatite: 1-apatite; 2 -kaolinite; 3 -sericite (muscovite). 


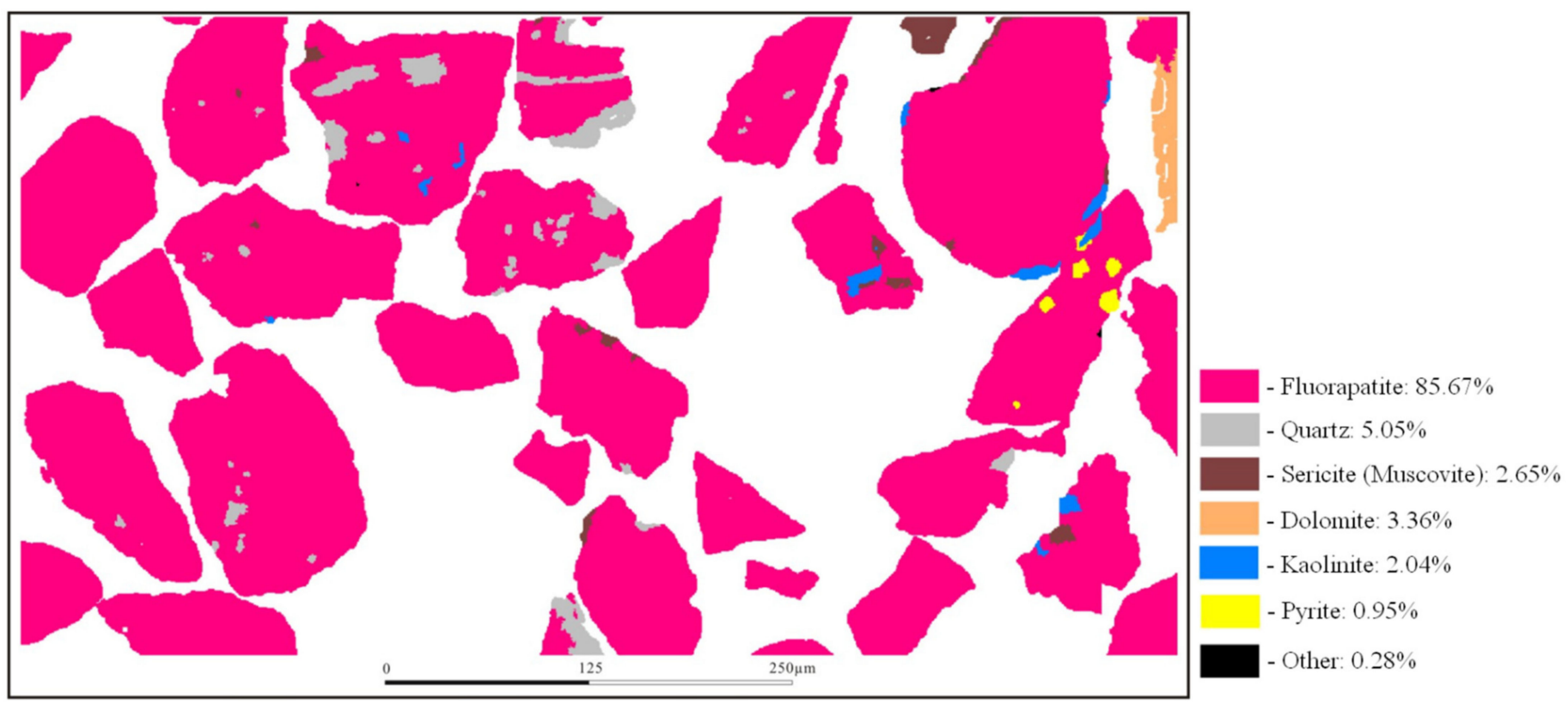

Figure 5. Apatite wrapped with fine-grained quartz, sericite (muscovite), kaolinite, pyrite, and dolomite.

(a)

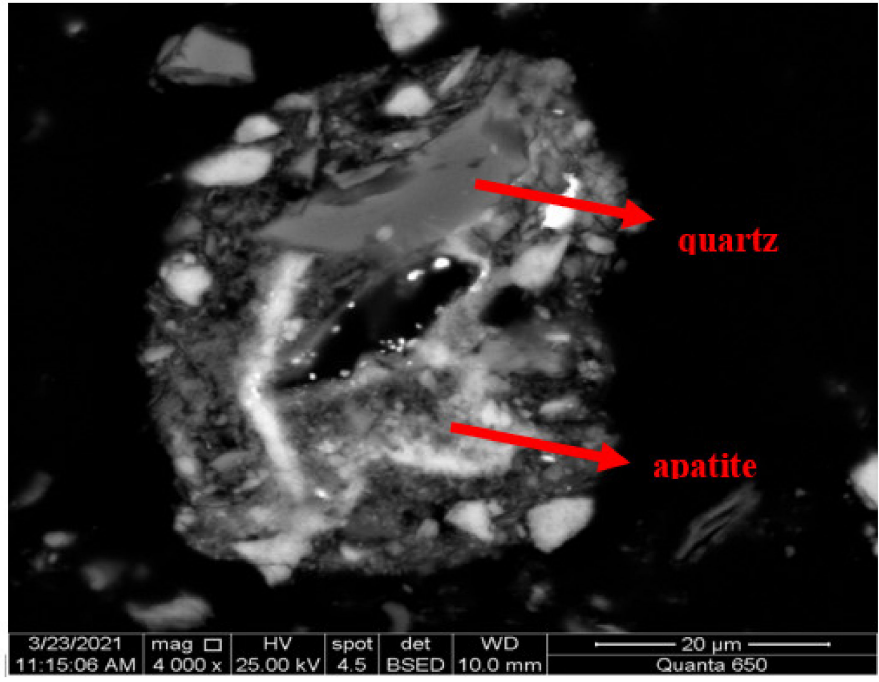

(b)

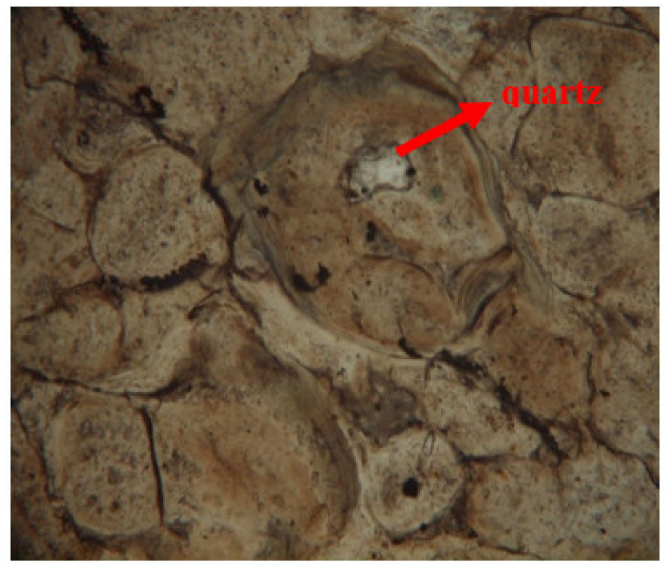

(c)

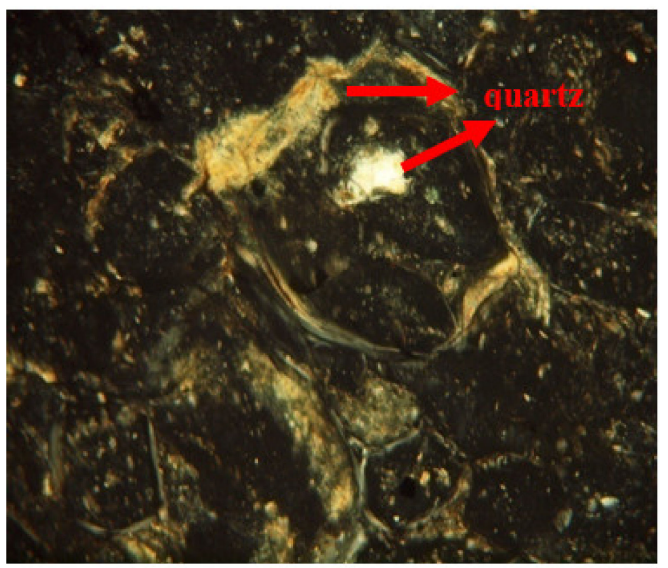

Figure 6. Cementation of microcrystalline quartz with apatite (like stromatolite): (a) BSED mode, (b) single polarization, and (c) orthogonal polarization. 
After the block ore is crushed and ground into powder granular products, some contain only one mineral, while some are useful minerals coexisting with gangue minerals. The former is called the monomer that has been liberated from the ore, and the latter is called the intergrowth of the mineral (e.g., adjacent shape, inclusion shape, etc.). The percentage of the monomer content of a mineral in the product to the total content of the mineral is called the mono-mineral liberation degree [13].The analysis of the liberation degree and intergrowth relationship of ore can help analyze and predict the possible behavior of mineral processing, which is crucial for selecting separation technology. We quantified the difference between monomer and intergrowth by the area percentage of mineral phase $(0 \%$, $0-25 \%, 25-50 \%, 50-75 \%, 75-100 \%$, and $100 \%$, respectively). The total number of mineral particles corresponding to different area percentages were counted, respectively, and the distribution rate of minerals was calculated, so as to obtain the mono-mineral liberation degree and intergrowth content. Herein, the mono-mineral liberation and intergrowth relationship of fluorapatite were statistically analyzed, as shown in Figures 7 and 8 . The mono-mineral liberation degree of fluorapatite was $62.49 \%$ when the content of particle size less than $75 \mu \mathrm{m}$ was $63 \%$. Still, the total content of rich intergrowth (area percentage, more than $75 \%$ ) and monomer was $92.95 \%$, and the content of poor intergrowth was less (Figure 7). Besides monomer, fluorapatite was mainly rich in fine-grained quartz, sericite (muscovite), and kaolinite by encapsulation (Figure 8), consistent with the previous description of the disseminated type. Moreover, this result explains the low mono-mineral liberation degree of fluorapatite in raw ore under the current grinding fineness, and we can improve the grinding fineness to achieve liberation.

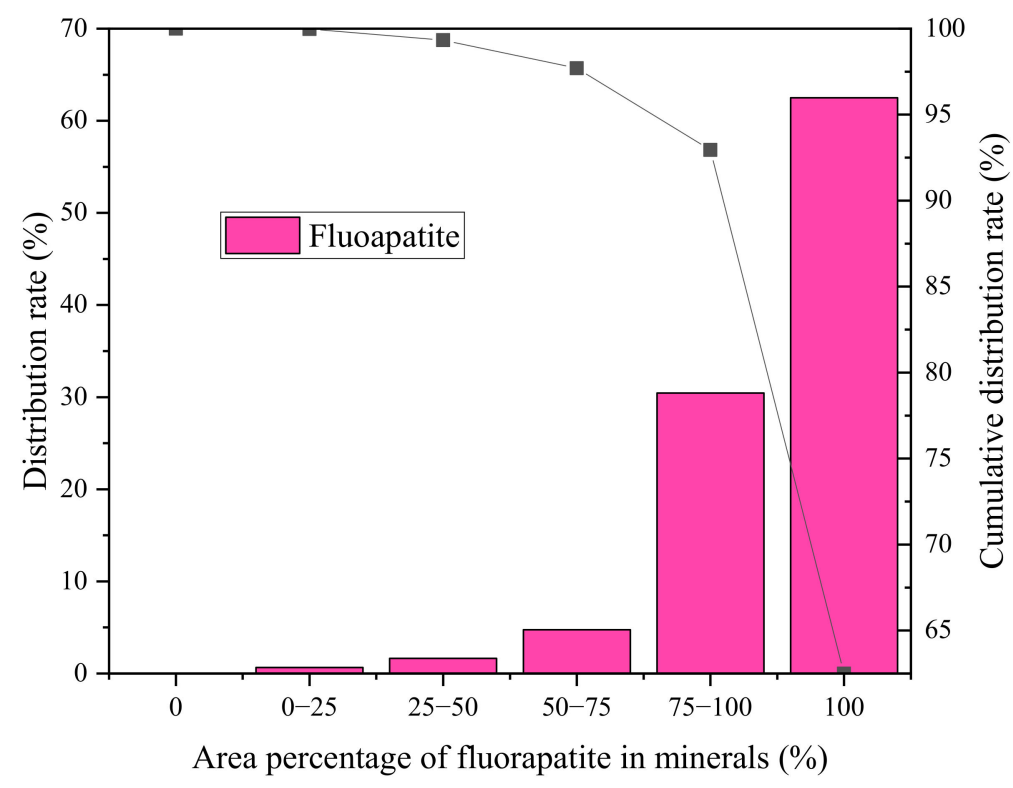

Figure 7. Mono-mineral liberation of fluorapatite: particle size of 0.52-212 $\mu \mathrm{m}$. 

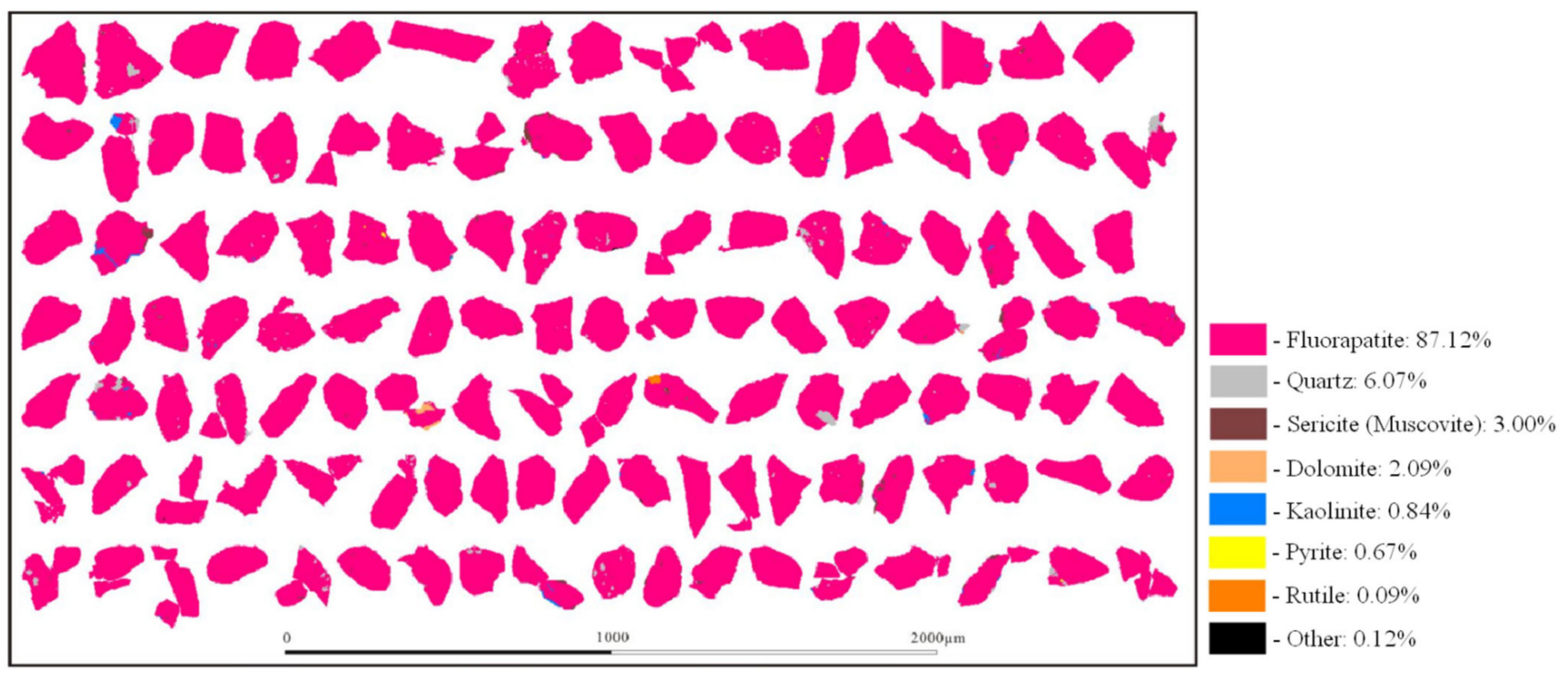

(a)

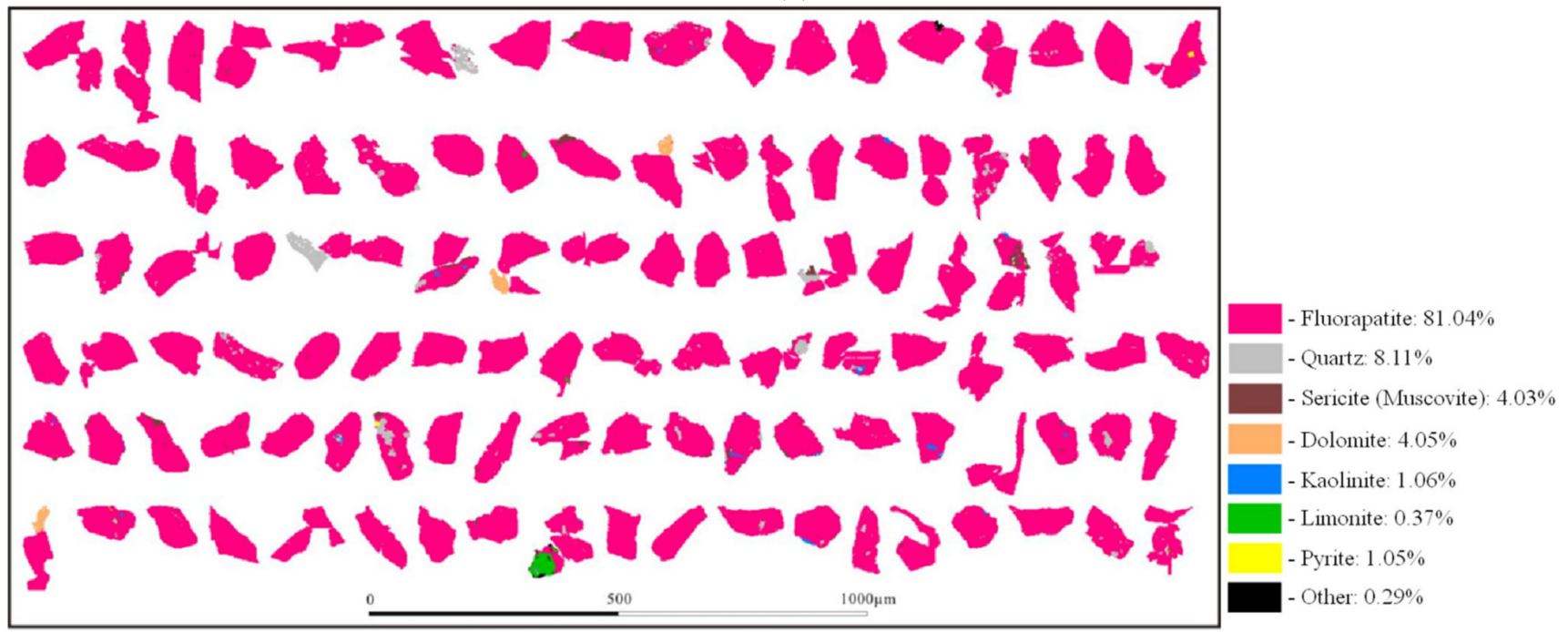

(b)

Figure 8. Intergrowth relationship between apatite and other minerals: (a) particle size of 75-212 $\mu \mathrm{m}$ and (b) particle size of $38-75 \mu \mathrm{m}$.

\subsection{Characteristics of Disseminated Particle Size of Main Minerals}

The research on ore particle size distribution characteristics can help select suitable crushing, grinding, and flotation processes [14]. The raw ore with particle size less than $75 \mu \mathrm{m}$ (content, 63\%) was wet-screened. The chemical composition and distribution rate of different grain sizes (+200 mesh, $200-400$ mesh, -400 mesh) are shown in Table 3. The histogram distribution of mineral composition in each grain size product is shown in Figure 9. $\mathrm{P}_{2} \mathrm{O}_{5}$ grade showed a downward trend with the gradual increase of ore fineness. In contrast, $\mathrm{MgO}, \mathrm{SiO}_{2}$, and $\mathrm{R}_{2} \mathrm{O}_{3}$ continuously increased with increasing ore fineness. The liberation effect improved as the particle size got finer. $\mathrm{MgO}, \mathrm{SiO}_{2}$, and $\mathrm{R}_{2} \mathrm{O}_{3}$ distribution in different grain size products were consistent with the yield. Their concentration distribution in grain size less than $38 \mu \mathrm{m}$ was $57.35 \%, 58.27 \%$, and $63.62 \%$, respectively, indicating the uniformity and regularity of grain size distribution of gangue minerals in the ore. Although the $\mathrm{P}_{2} \mathrm{O}_{5}$ content was inversely proportional to $\mathrm{MgO}, \mathrm{SiO}_{2}$, and $\mathrm{R}_{2} \mathrm{O}_{3}$ contents, the grade of $\mathrm{P}_{2} \mathrm{O}_{5}$ was up to $23.98 \%$ with a yield of $41.19 \%$ in the products with the grain size less than $38 \mu \mathrm{m}$, indicating that a considerable part of fluorapatite was distributed in fine grains 
with complex co-relationship with gangue minerals. The above results are consistent with the distribution of gangue minerals (Figure 9).

Table 3. Chemical composition and distribution rate of raw ore products with different grain sizes.

\begin{tabular}{|c|c|c|c|c|c|c|c|c|c|c|c|c|c|}
\hline \multirow{2}{*}{$\begin{array}{l}\text { Grain } \\
\text { Size } \\
\text { (Mesh) }\end{array}$} & \multicolumn{3}{|c|}{ Yield (wt. \%) } & \multicolumn{5}{|c|}{ Grade (wt. \%) } & \multicolumn{5}{|c|}{ Distribution Rate (wt. \%) } \\
\hline & Individual & $\begin{array}{l}\text { Accumulation } \\
\text { on Sieve }\end{array}$ & $\begin{array}{l}\text { Accumulation } \\
\text { under Sieve }\end{array}$ & $\mathrm{P}_{2} \mathrm{O}_{5}$ & $\mathrm{MgO}$ & $\mathrm{SiO}_{2}$ & $\mathrm{Al}_{2} \mathrm{O}_{3}$ & $\mathrm{Fe}_{2} \mathrm{O}_{3}$ & $\mathrm{P}_{2} \mathrm{O}_{5}$ & $\mathrm{MgO}$ & $\mathrm{SiO}_{2}$ & $\mathrm{Al}_{2} \mathrm{O}_{3}$ & $\mathrm{Fe}_{2} \mathrm{O}_{3}$ \\
\hline+200 & 36.93 & 36.93 & 100.00 & 33.90 & 0.90 & 8.45 & 1.93 & 0.96 & 42.91 & 22.23 & 23.30 & 19.14 & 22.93 \\
\hline $200-400$ & 21.88 & 58.81 & 63.07 & 30.94 & 1.40 & 11.29 & 2.51 & 1.35 & 23.21 & 20.42 & 18.43 & 14.76 & 19.06 \\
\hline-400 & 41.19 & 100.00 & 41.19 & 23.98 & 2.09 & 18.95 & 5.96 & 2.18 & 33.88 & 57.35 & 58.27 & 66.10 & 58.01 \\
\hline Total & 100.00 & & & 29.17 & 1.50 & 13.40 & 3.72 & 1.55 & 100.00 & 100.00 & 100.00 & 100.00 & 100.00 \\
\hline
\end{tabular}

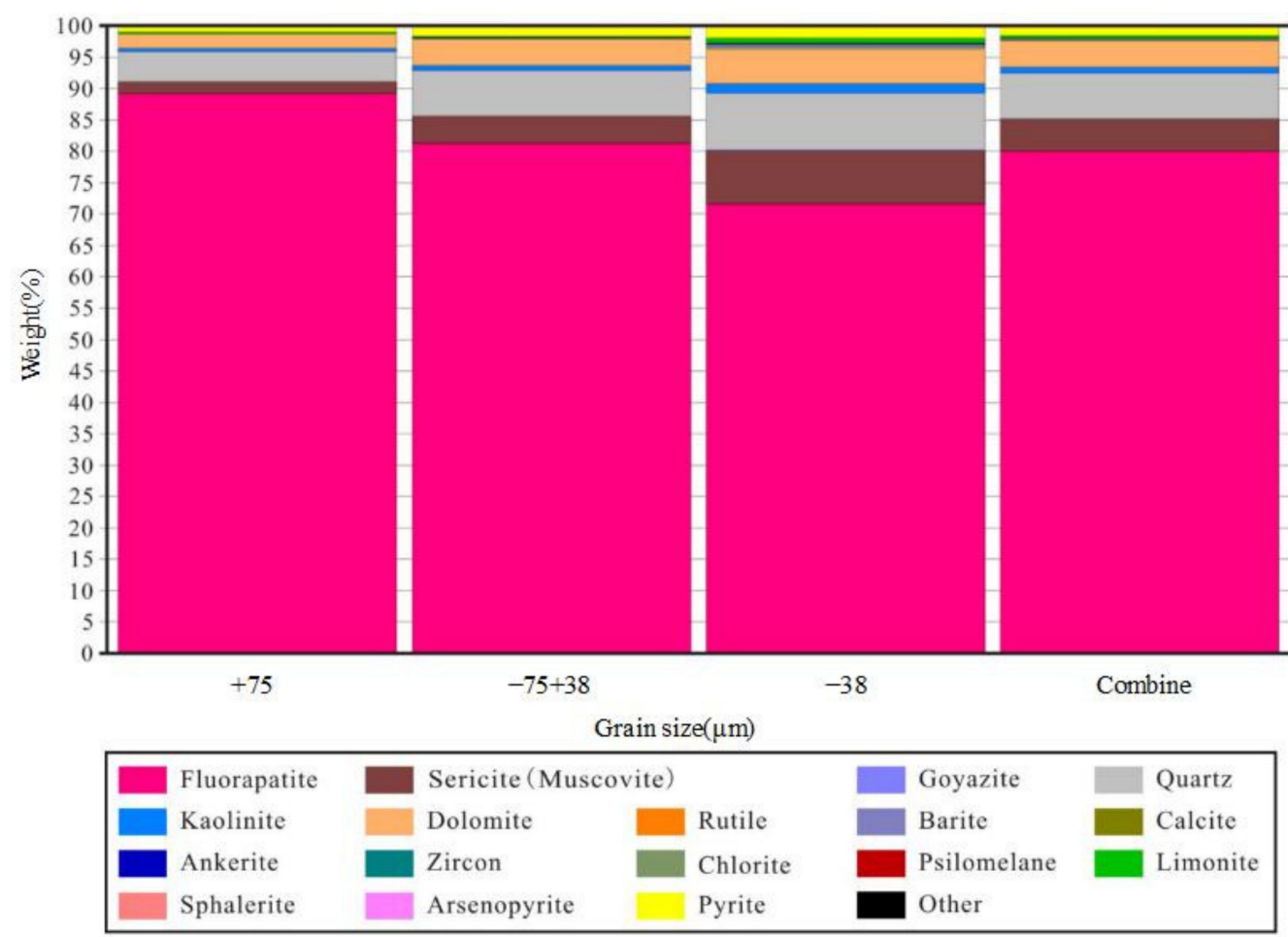

Figure 9. Histogram distribution of mineral composition in different grain size products.

New particles are formed along or across the lattice during the grinding process as the particle size decreases. The comminution process of fluoroapatite is mainly through the lattice to produce fresh fracture surfaces. Unlike fluorapatite, gangue minerals (quartz, silicate, dolomite, etc.) are mainly fractured along the lattice direction [15]. The particle size statistical analysis of seven minerals was conducted (Figure 10) to further clarify the distribution of target mineral (fluorapatite) and gangue minerals (quartz, sericite (muscovite), kaolinite, pyrite, limonite, and dolomite) in different grain sizes. The grain size of the main minerals in the ore was fine on the whole, mainly within $75 \mu \mathrm{m}$ (Figure 10a-f). The fraction of grain size less than $20 \mu \mathrm{m}$ was relatively large, significant enrichment characteristics of fine particles, especially for gangue minerals. Fluoroapatite of particle size within $75 \mu \mathrm{m}$, less than $20 \mu \mathrm{m}, 38-75 \mu \mathrm{m}$, and $75-150 \mu \mathrm{m}$ accounted for $73.01 \%, 23.79 \%, 30.51 \%$, and $25.88 \%$, respectively. The overall embedded particle size of fluoroapatite was relatively coarse and unevenly distributed. Quartz of particle size within $75 \mu \mathrm{m}$ and less than $20 \mu \mathrm{m}$ accounted for $92.21 \%$ and $48.54 \%$, respectively. Sericite (muscovite) and kaolinite with particle size within $75 \mu \mathrm{m}$ accounted for $97.64 \%$ and $96.68 \%$, respectively, and those with particle size less than $10 \mu \mathrm{m}$ accounted for $46.42 \%$ and $54.90 \%$, respectively. Pyrite with particle size within $75 \mu \mathrm{m}, 20-38 \mu \mathrm{m}$, and 38-75 $\mu \mathrm{m}$ accounted for $89.51 \%, 25.69 \%$, and $29.84 \%$, respectively. Limonite with particle size within $75 \mu \mathrm{m}$, below $10 \mu \mathrm{m}$, and $10-20 \mu \mathrm{m}$ accounted for $91.39 \%, 43.84 \%$, and $24.82 \%$, respectively. In contrast, some gangue minerals containing aluminum and iron with particle size below $10 \mu \mathrm{m}$ accounted for the highest 
proportion of ultrafine particles and significant argillization, which may have the characteristics of fine embedded particle size, small hardness, and easy processing into ultrafine particles [16]. Dolomite with particle size within $75 \mu \mathrm{m}$, below $10 \mu \mathrm{m}$, and 38-75 $\mu \mathrm{m}$ accounted for $87.90 \%, 34.53 \%$ and $23.52 \%$, respectively. Dolomite had a lower hardness than quartz, thus easy to make it overground and slime in the grinding stage [17]. The above data indicate that the ore was fine-grained collophanite. Although a better mineral liberation degree can be obtained by increasing the grinding fineness of the ore. However, increased fineness can also aggravate the mineral argillization and increase the viscosity of the mineralized foam, thus increasing the difficulty of flotation separation of fluorapatite and gangue minerals.

\subsection{Liberation Degree and Intergrowth Characteristics of Main Gangue Minerals}

The mono-mineral liberation degree and intergrowth of six main gangue minerals are shown in Figures 11 and 12. The mono-mineral liberation degree of quartz was $44.46 \%$, and the intergrowth content was $55.54 \%$ (rich and poor intergrowth were $35.48 \%$ and $19 \%$, respectively) when the particle size below $75 \mu \mathrm{m}$ accounted for 63\% (Figure 11). Quartz was mainly associated with fluorapatite, sericite (muscovite), kaolinite, etc. (Figure 12a). Moreover, quartz was mainly rich in fluoroapatite, which could be liberated under suitable fineness. A small amount of quartz wrapped fluoroapatite, which was not easy to be completely liberated. The mono-mineral liberation degree of sericite (muscovite) was $55.58 \%$ (the content of rich and poor intergrowth was $28.07 \%$ and $15.67 \%$, respectively) (Figure 11). Sericite (Muscovite) was mainly rich in fluoroapatite by encapsulation. A small part of sericite (muscovite) was rich in quartz and kaolinite by encapsulation, and poor in fluoroapatite and kaolinite (Figure 12b). The particle size of the wrapped fluoroapatite was mostly less than $0.03 \mathrm{~mm}$, which was not easy to be completely liberated. The mono-mineral liberation degree of kaolinite was $35.48 \%$, and the content of intergrowth was $62.71 \%$ (rich and poor intergrowth were $27.39 \%$ and $35.32 \%$, respectively) (Figure 11). Kaolinite was mainly associated with fluoroapatite, sericite (muscovite), and quartz (Figure 12c). Kaolinite was mainly poor or semi-regular intergrowth with fluoroapatite, which was easy to liberate by improving grinding fineness. Furthermore, kaolinite and fluoroapatite formed mutual inclusion. Fine fluoroapatite was wrapped in kaolinite. Fine kaolinite was wrapped in fluoroapatite and was not easy to completely liberate. The mono-mineral liberation degree of pyrite was $40.97 \%$, and the intergrowth content was $59.03 \%$ (rich and poor intergrowth were $43.43 \%$ and $14.75 \%$, respectively) (Figure 11). Pyrite was mainly rich in fluorapatite. It was rich in quartz, kaolinite, etc. by encapsulation (Figure 12d). The mono-mineral liberation degree of limonite was $43.29 \%$, and the intergrowth content was $56.71 \%$ (rich and poor intergrowth were $30.13 \%$ and $23.89 \%$, respectively) (Figure 11 ). Limonite was mainly rich in fluoropatite, sericite (muscovite), quartz, etc. (Figure 12e). The mono-mineral liberation degree of dolomite was $84.62 \%$, and the content of intergrowth was $15.38 \%$ (Figure 11). Dolomite was mainly rich in fluoroapatite, quartz, sericite (muscovite), and pyrite (Figure 12f). Dolomite was mainly poor in fluoroapatite, which was easy to liberate under suitable fineness. Moreover, a small amount of dolomite was rich in kaolinite, which was rare. In conclusion, silica (aluminum) and iron gangue minerals in the ore have poor liberation degree and are rich in ultrafine mineral particles, which can lead to a low removal rate of gangue minerals, and substantial $\mathrm{P}_{2} \mathrm{O}_{5}$ loss in the flotation process [18]. 

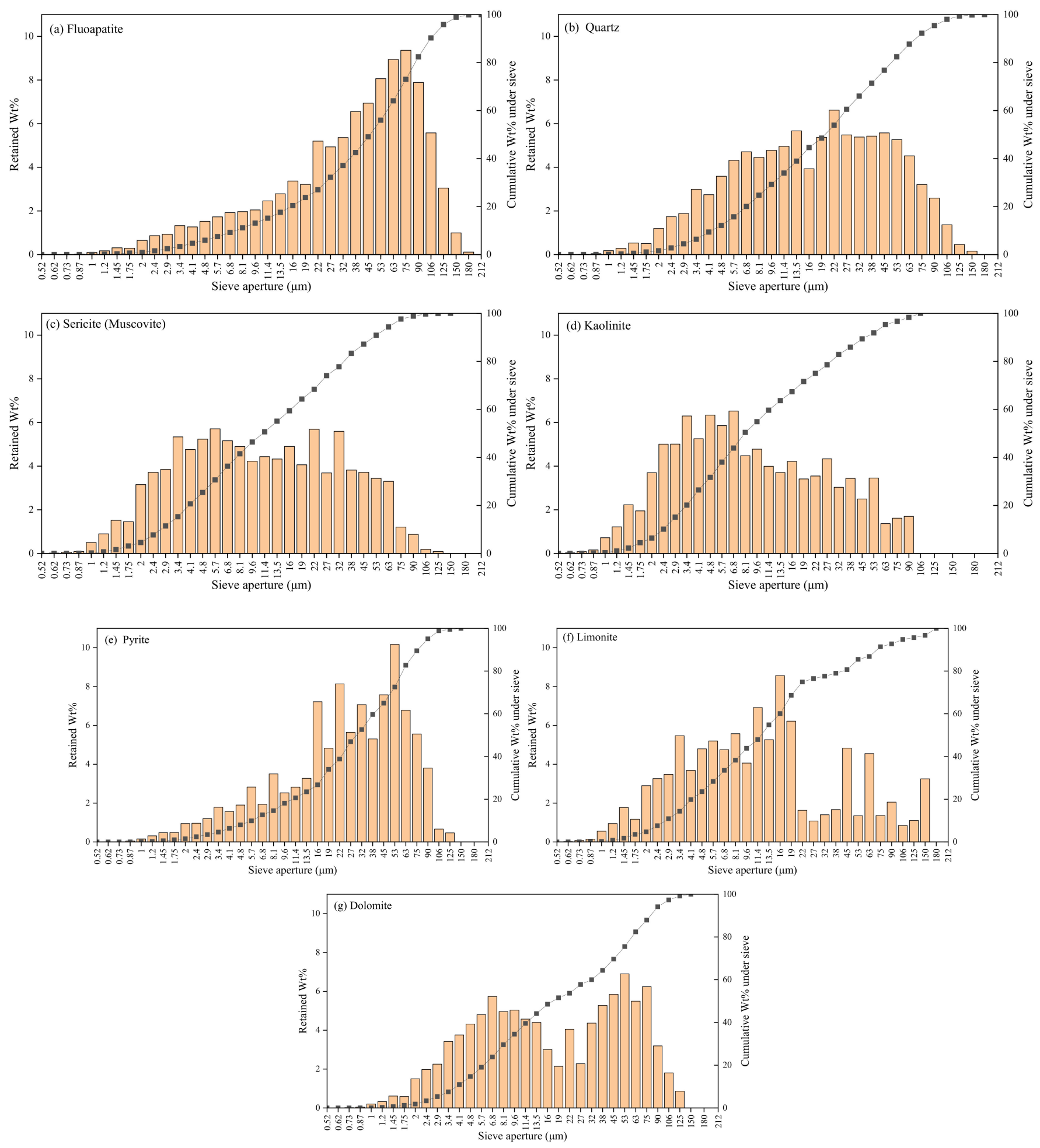

Figure 10. Grain size statistics of target minerals and main gangue minerals: (a) fluorapatite, (b) quartz, (c) sericite (muscovite), (d) kaolinite, (e) pyrite, (f) limonite, and (g) dolomite. 


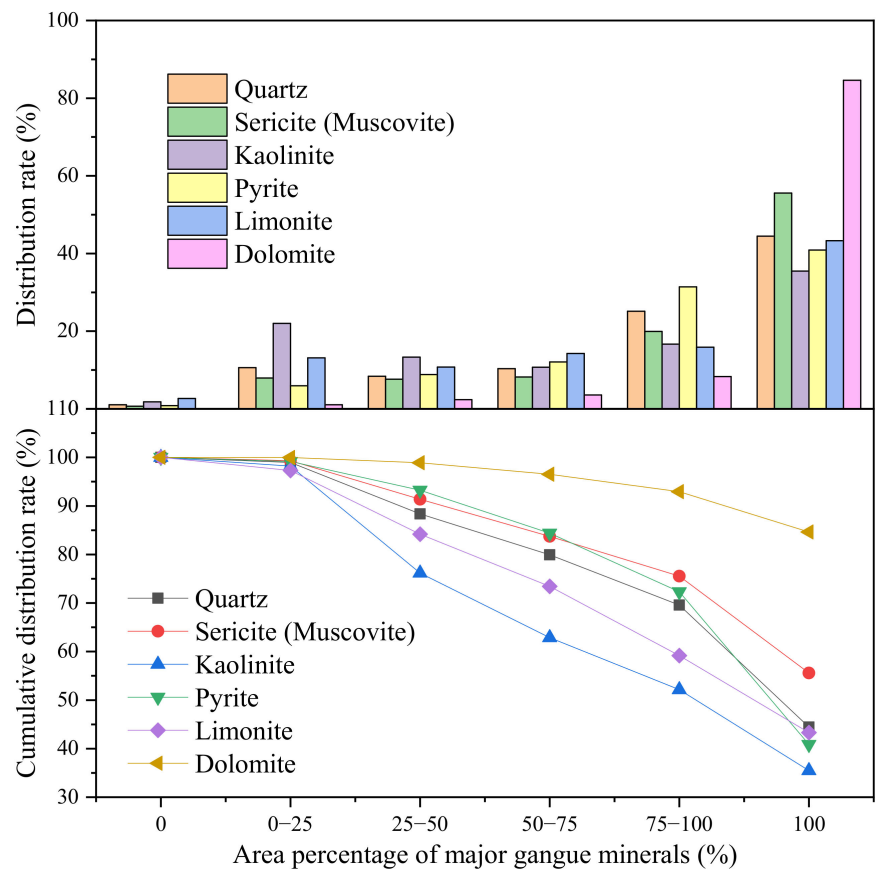

Figure 11. Statistics of mono-mineral liberation degree of major gangue minerals: particle size of $0.52-212 \mu \mathrm{m}$.

(a)

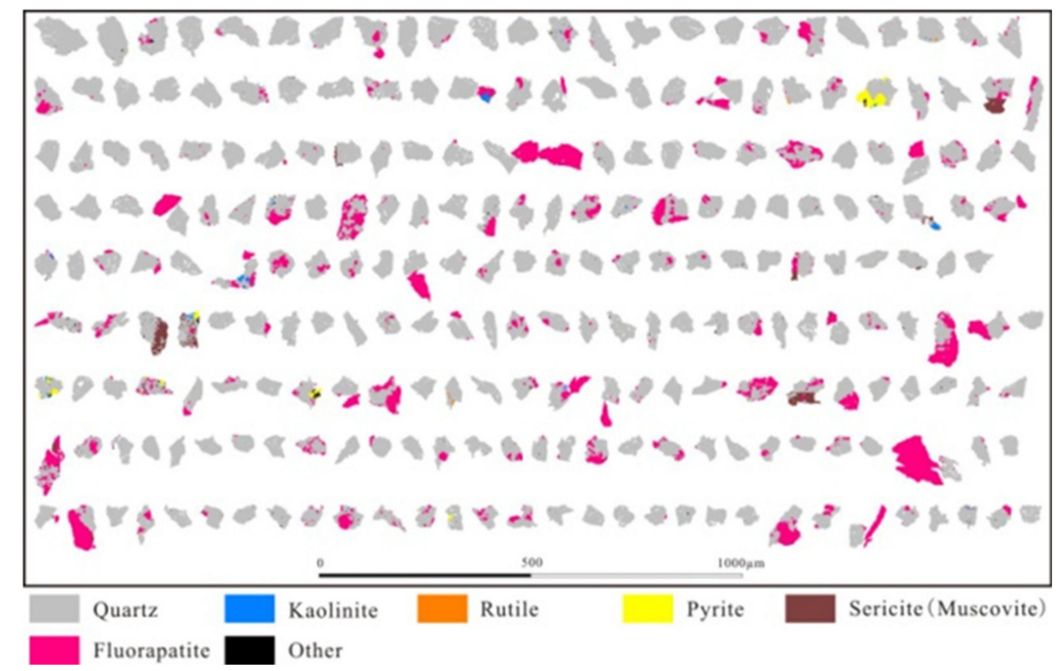

(b)

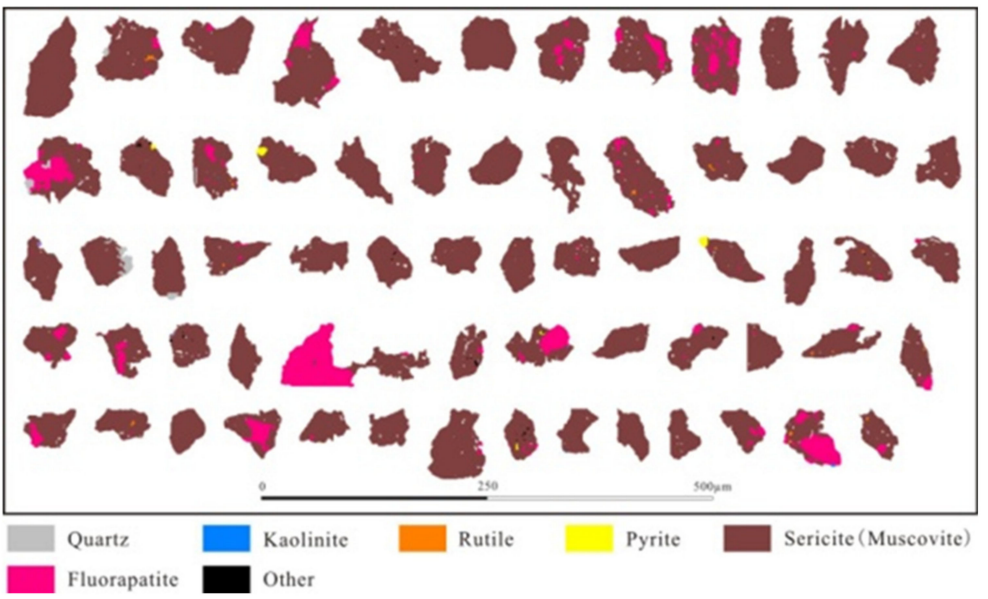

Figure 12. Cont. 
(c)

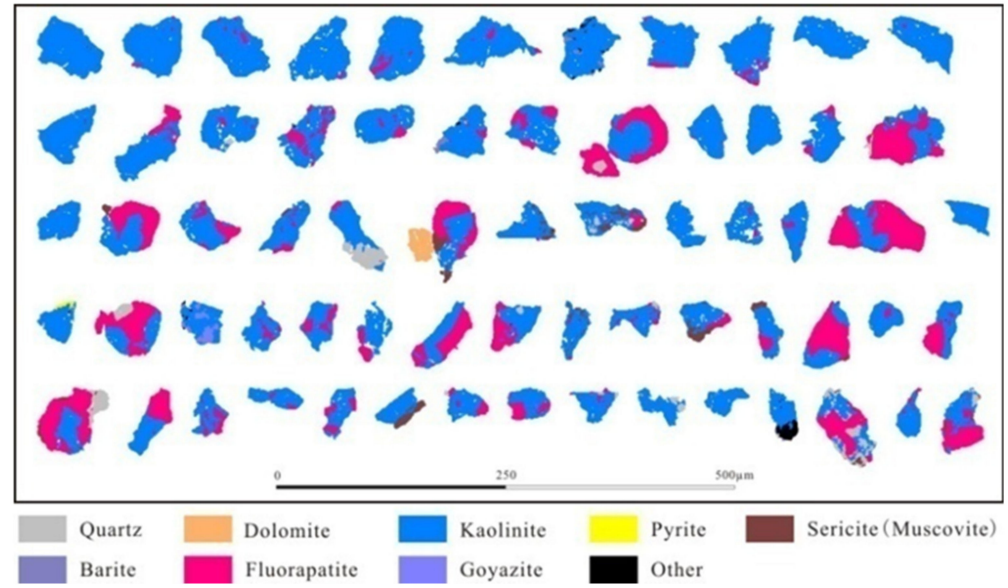

(d)

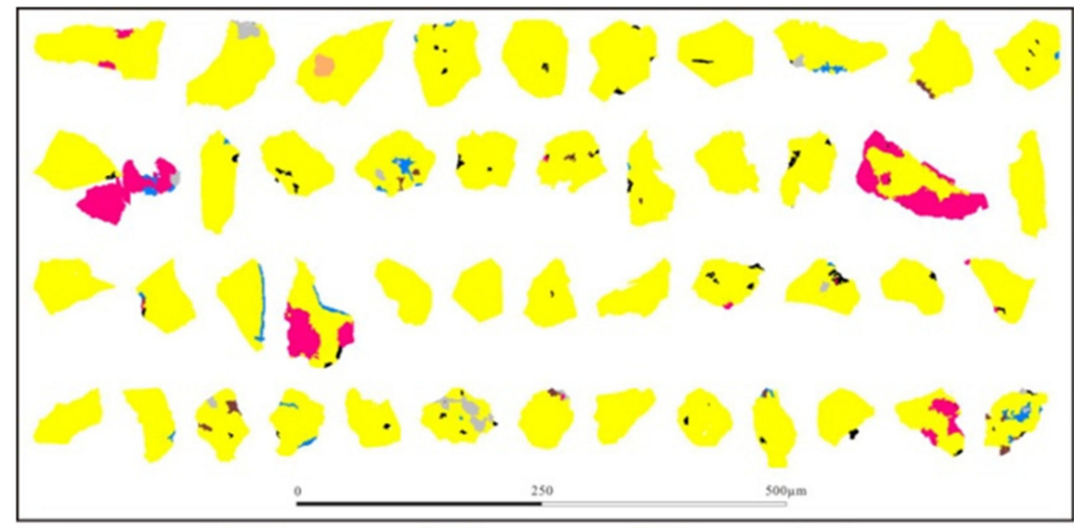

Quartz Dolomite $\square$ Kaolinite $\quad$ Pyrite $\quad$ Sericite(Muscovite)

Fluorapatite

Other

(e)

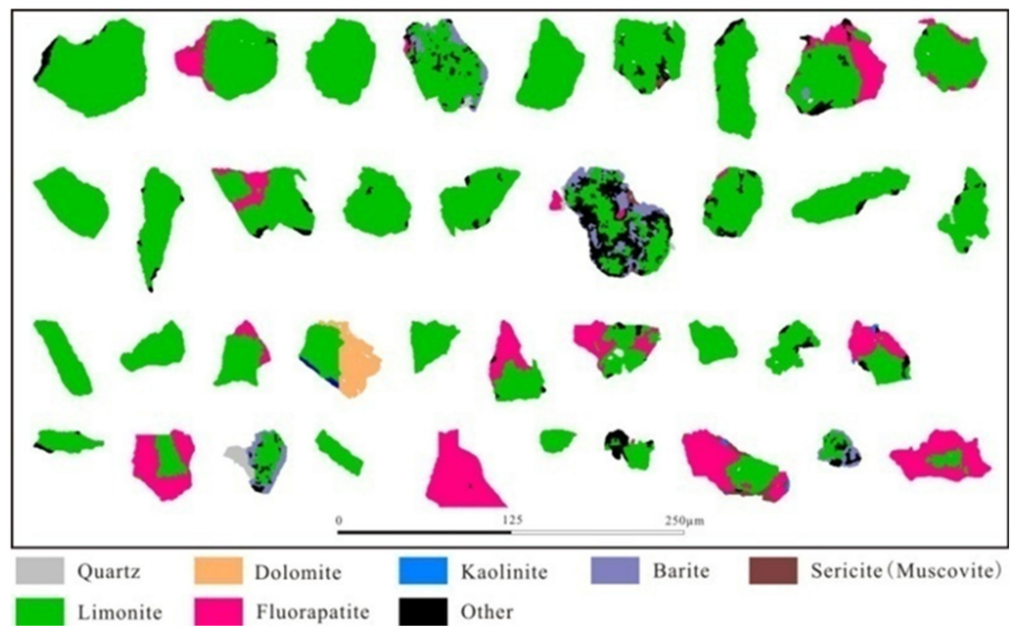

Figure 12. Cont. 
(f)

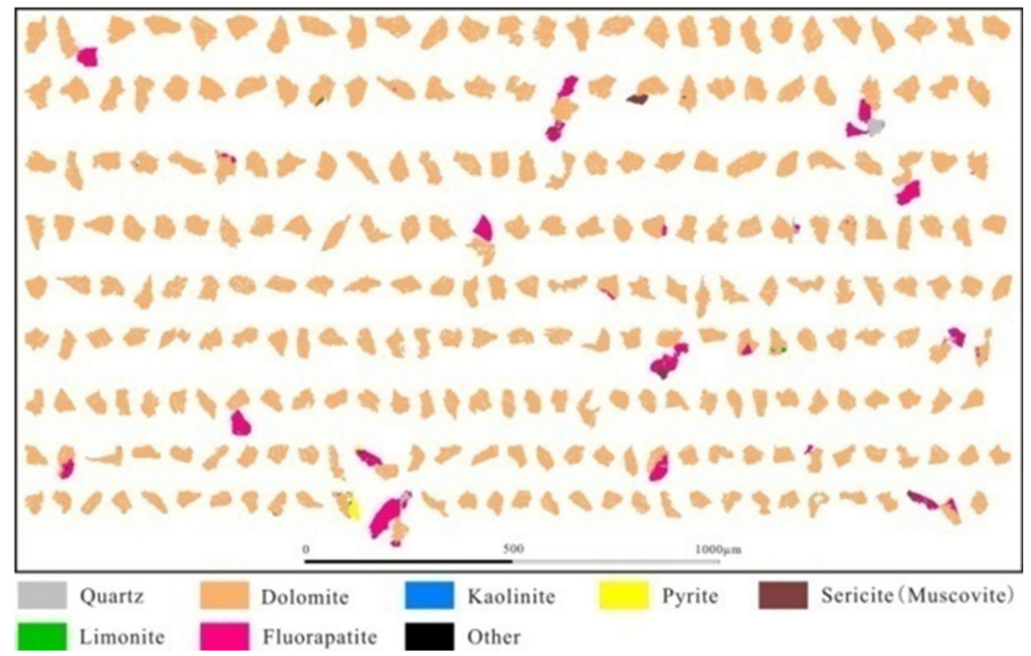

Figure 12. Intergrowth relationship between each gangue mineral and other minerals (particle size of 38-75 $\mu \mathrm{m}$ ): (a) quartz, (b) sericite (muscovite), (c) kaolinite, (d) pyrite, (e) limonite, and (f) dolomite.

\subsection{Application in Flotation}

The above process mineralogical information indicated that the phosphate ore was a high-grade calcareous-siliceous collophanite, and the content of major impurities (e.g., Fe, $\mathrm{Al}, \mathrm{Mg}$, Si, etc.) was significantly lower than that of $\mathrm{P}_{2} \mathrm{O}_{5}$. Silicate mainly occurred in quartz and sericite (muscovite). Aluminum mainly occurred in sericite (muscovite), kaolinite. Magnesium mainly occurred in dolomite. Iron mainly occurred in pyrite and limonite, and a small amount in sericite (muscovite).Carbonate and silicate gangue minerals should be removed in the ore to obtain a high-quality phosphorus concentrate with $\mathrm{MgO}$ and sesquioxide contents less than $1 \%$ and $2.5 \%$, respectively. The reverse flotation process is the best choice based on the principle of less flotation and more inhibition. However, gangue minerals, such as quartz and sericite (muscovite) in the ore were fine disseminated and wrapped by fluoroapatite particles with complex co-associated relationships. This is not conducive to the smooth implementation of flotation. Moreover, the mono-mineral liberation degree of fluorapatite under the current grinding fineness $(-75 \mu \mathrm{m}$ accounting for $63 \%$ ) was low, only $62.49 \%$. It is necessary to increase the grinding fineness to obtain a higher mono-mineral liberation degree. However, too fine particle size can aggravate argillization and increase the viscosity of mineralized foam, resulting in phosphorus loss and difficult flotation operation $[19,20]$. Based on our previous experience in process research, the double reverse flotation process under coarse particle size conditions was assessed to reduce the pressure of foam flotation for removing silicon (Figure 13). A phosphorous concentrate with $\mathrm{P}_{2} \mathrm{O}_{5}$ grade of $35.53 \%, \mathrm{SiO}_{2}$ content of $5.88 \%, \mathrm{MgO}$ content of $0.91 \%, \mathrm{R}_{2} \mathrm{O}_{3}$ content of $1.98 \%$, MER value of $8.13 \%$, and phosphorus recovery rate of $75.04 \%$ was obtained under reverse flotation with two roughings and four refinings. The XRD patterns of concentrate and tailings are shown in Figure 14. The diffraction intensity and content distribution of collophanite (fluorapatite), dolomite, and siliceous minerals in each separation product were significantly different compared with the raw ore (Figure 1), consistent with the results of chemical element analysis, showing a better separation effect. 


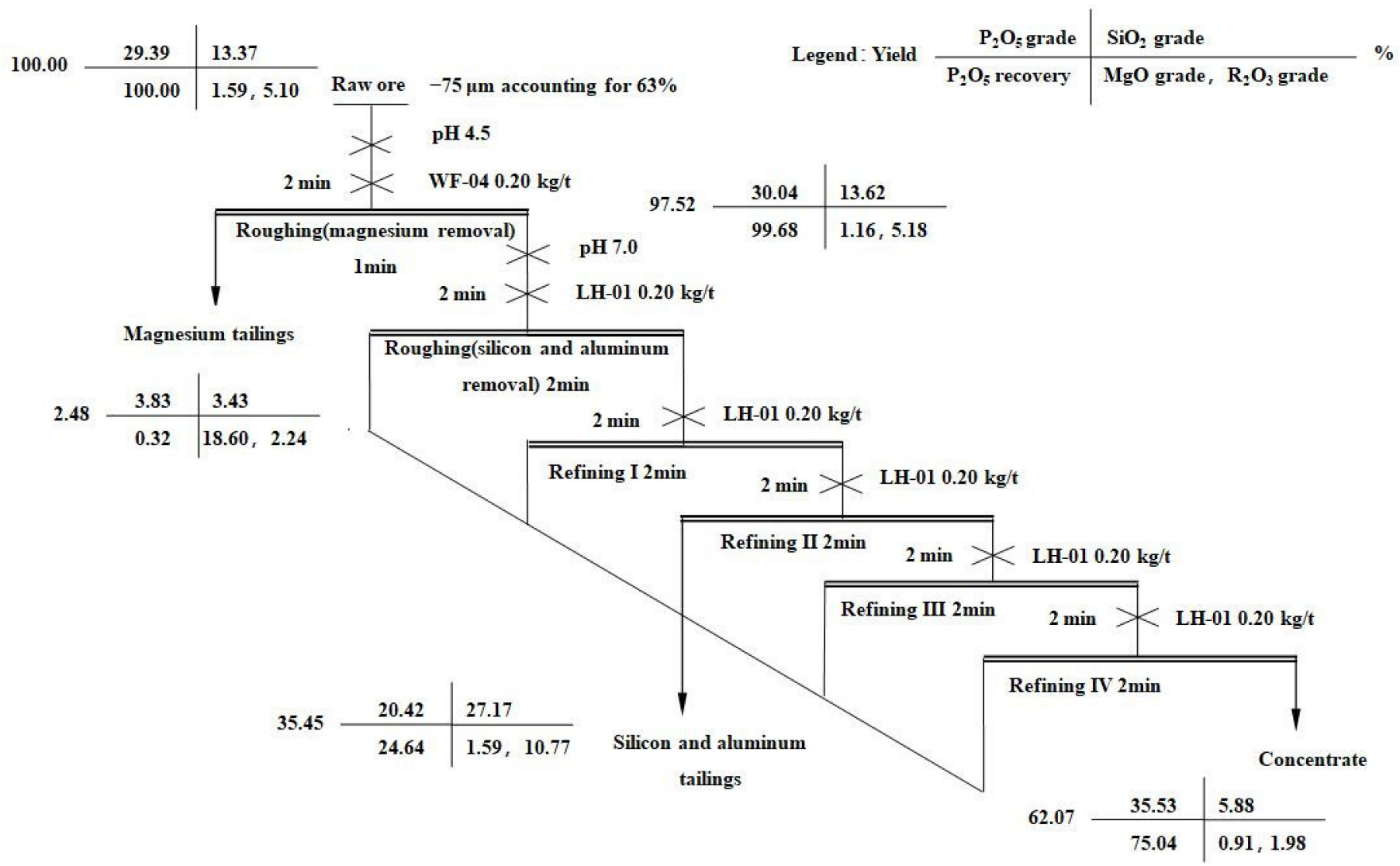

Figure 13. Numerical quality flow chart of double reverse flotation of collophanite with particle size of $-75 \mu \mathrm{m}$ accounting for $63 \%$.

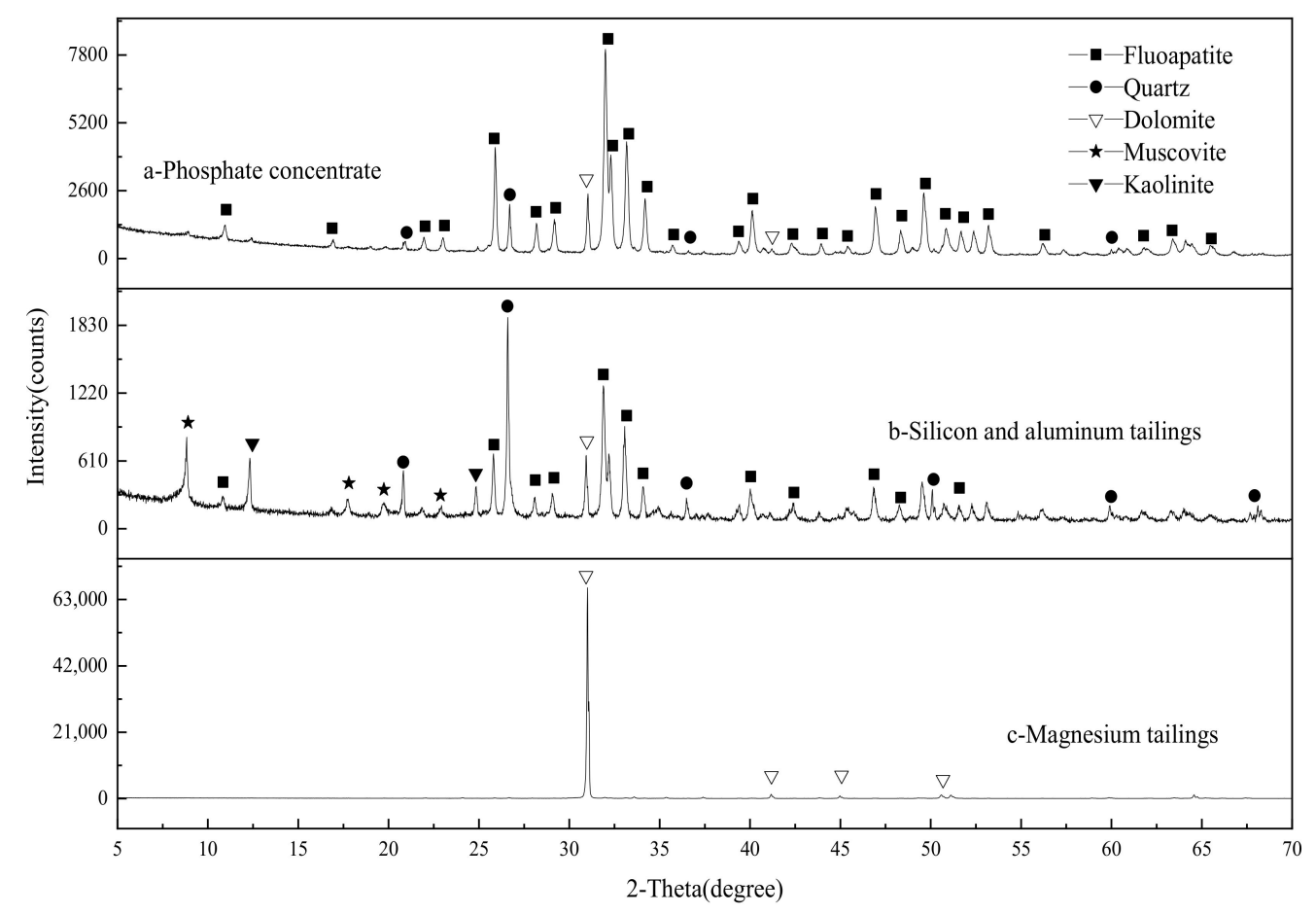

Figure 14. XRD diffraction patterns of concentrate and tailings after flotation. 
Wet-screening analysis was conducted on concentrate, magnesium tailings, and silicon tailings. The distribution of $\mathrm{P}_{2} \mathrm{O}_{5}$ in different grain sizes of each product was also investigated (Figure 15). The results showed significant enrichment characteristics of fine-grained fluorapatite in silica tailings, and the $\mathrm{P}_{2} \mathrm{O}_{5}$ recovery rate of $-38 \mu \mathrm{m}$ particle size product was up to $18.51 \%$. The SEM_EDS mapping of phosphorus and silicon in desilication tailings is shown in Figure 16. Some coarse-grained fluorapatite in desilication tailings was rich in siliceous gangue minerals. Furthermore, some fine-grained apatite was closely associated with siliceous minerals, making the selective separation difficult and thus leading to a high $\mathrm{P}_{2} \mathrm{O}_{5}$ recovery rate. It is necessary to increase the grinding fineness for higher mono-mineral liberation degree. Furthermore, for the selected raw ore, the $-38 \mu \mathrm{m}$ fraction accounted for $41.19 \%$ (Table 3). Although this part of fluorapatite had a relatively better mono-mineral liberation degree, the particle size distribution was too fine, showing argillization phenomenon. Meanwhile, several fine particles can increase the consumption of reagents and slurry viscosity. The inevitable mechanical entraining behavior can also lead to useful minerals directly into the foam products [21]. Yao et al. [22,23] showed that some micro-fine useful minerals are non-selectively adsorbed on the surface of relatively coarse gangue minerals, forming a hydrophilic "armor", thus impeding the interaction of gangue minerals with collectors/bubbles and reducing the floatability of gangue minerals. Gangue minerals can be effectively removed only by increasing the amount of collector or using highly efficient dispersion inhibitors. Hoang et al. [24] showed that the adverse rheological effect in flotation pulps can also enhance fine particle entrainment. Furthermore, in the flotation process of traditional flotation machine, the defects, such as thin foam layer can lead to the significant fine particle entrainment $[25,26]$. The fine disseminated particle size, poor mineral liberation degree, and severe argillization causes the difficulty in collophanite separation. The selection of foam-controlled collectors, efficient dispersing inhibitors and classified desliming process will be necessary for improving flotation index.

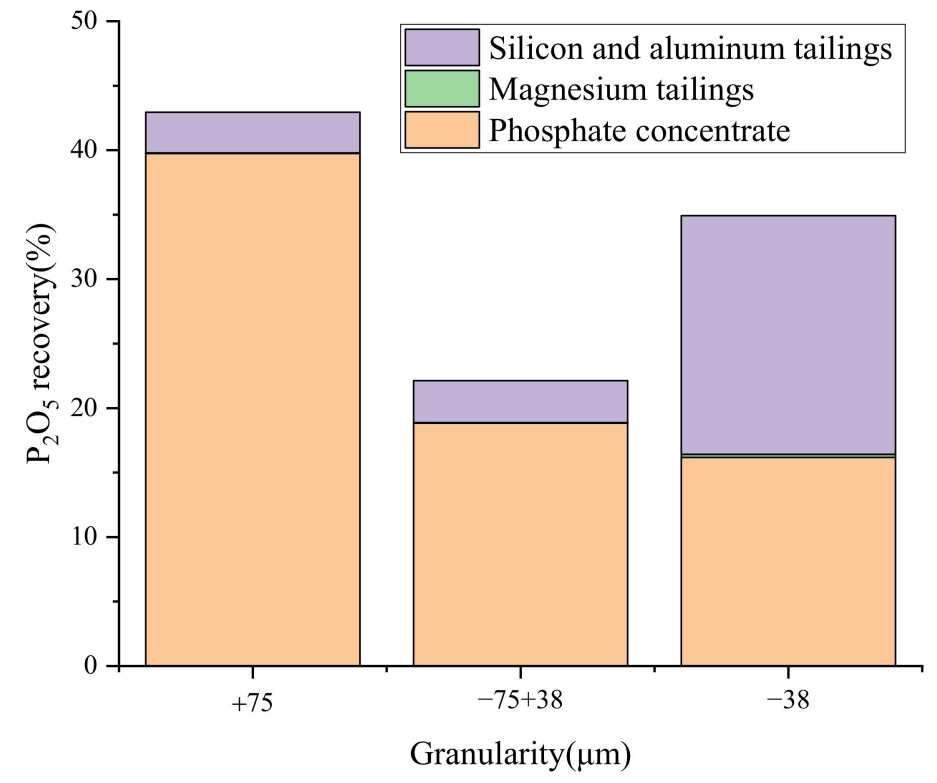

Figure 15. Relationship between particle size of each product after flotation and $\mathrm{P}_{2} \mathrm{O}_{5}$ recovery. 


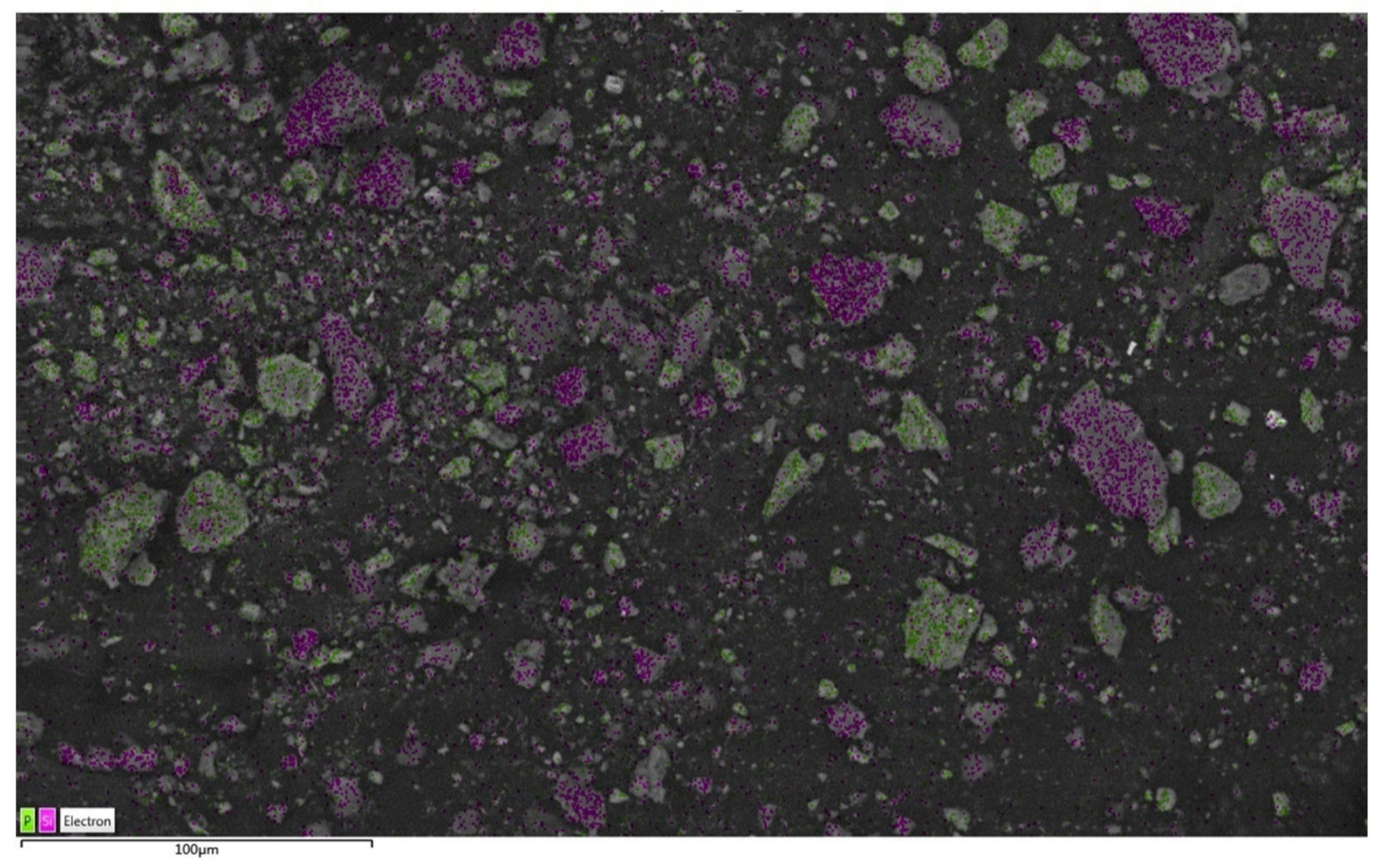

Figure 16. SEM_EDS surface distribution of phosphorus and silicon in silicon tailings after flotation.

\section{Conclusions}

(1) The phosphate ore was a fine-grained calcareous-siliceous collophanite, with $\mathrm{P}_{2} \mathrm{O}_{5}$ grade of $29.40 \%, \mathrm{SiO}_{2}$ content of $13.37 \%, \mathrm{MgO}$ content of $1.47 \%$, sesquioxide $\left(\mathrm{Al}_{2} \mathrm{O}_{3}+\right.$ $\left.\mathrm{Fe}_{2} \mathrm{O}_{3}\right)$ content of $4.91 \%$, MER value $\left(\omega\left(\mathrm{MgO}+\mathrm{Al}_{2} \mathrm{O}_{3}+\mathrm{Fe}_{2} \mathrm{O}_{3}\right) / \omega\left(\mathrm{P}_{2} \mathrm{O}_{5}\right)\right)$ of $21.70 \%$, and $\omega(\mathrm{CaO}) / \omega\left(\mathrm{P}_{2} \mathrm{O}_{5}\right)$ value of $1.43(>1.40)$. The ore had a complex mineral composition, of which fluorapatite was the main target mineral (79.76\%). Gangue minerals included quartz, sericite (muscovite), kaolinite, dolomite, pyrite, and limonite $(7.17 \%, 5.18 \%, 1.04 \%, 4.02 \%$, $1.53 \%$, and $0.48 \%$, respectively).

(2) Phosphorus in the ore mainly occurred in fluoroapatite. The disseminated type of fluoroapatite was mainly granular, with a particle size of $0.005-0.19 \mathrm{~mm}$, and closely associated with gangue minerals, such as sericite (muscovite) and kaolinite. Part of apatite was wrapped in gangue minerals as fine particles. Besides, gangue minerals, such as fine-grained quartz, sericite (muscovite), and kaolinite were also wrapped in part of apatite, and the particle size of most wrapped minerals was less than $0.04 \mathrm{~mm}$, which was not easy to be completely liberate. The liberation degree of fluoroapatite was $62.49 \%$ when the content of particle size less than $75 \mu \mathrm{m}$ was 63\%. Besides monomers, fluoroapatite was mainly rich in fine-grained quartz, sericite (muscovite), and kaolinite by encapsulation, of which the total content of rich intergrowth (area percentage, more than 75\%) and monomer is $92.95 \%$, while the content of poor intergrowth is less. Gangue minerals, such as quartz, sericite (muscovite), kaolinite, and dolomite had fine disseminated particle size with particle size less than $75 \mu \mathrm{m}$. The content of particle size less than $20 \mu \mathrm{m}$ was relatively high, with significant argillization characteristics. Moreover, gangue minerals were closely related to fluorapatite, mainly characterized by rich or semi-regular intergrowth, with poor mono-mineral liberation.

(3) A phosphorous concentrate with a $\mathrm{P}_{2} \mathrm{O}_{5}$ grade of $35.53 \%, \mathrm{SiO}_{2}$ content of $5.88 \%$, $\mathrm{MgO}$ content of $0.91 \%, \mathrm{R}_{2} \mathrm{O}_{3}$ content of $1.98 \%$, MER value of $8.13 \%$, and phosphorus recovery rate of $75.04 \%$ was obtained through double reverse flotation process under the condition of coarse particle size. It can be used as a superior phosphate ore for wet-process 
phosphoric acid production. The double reverse flotation process preliminarily realized the removal of carbonate and silicate gangue minerals in the ore. However, the recovery rate of $\mathrm{P}_{2} \mathrm{O}_{5}$ in desilication tailings after separation was high. The element distribution map on the surface of silicon tailings showed that some coarse-grained fluoroapatite was rich in siliceous gangue minerals, and a part of fine-grained apatite was closely associated with siliceous minerals. Highly selective flotation may be difficult to achieve under current process conditions. Although a better mineral liberation degree can be obtained by increasing the grinding fineness of the ore. However, excessive fineness can aggravate the mineral argillization and increase the viscosity of the mineralized foam, thus increasing the difficulty of flotation separation of fluorapatite and gangue minerals.

(4) In summary, fine disseminated particle size, poor mineral liberation degree, and serious argillization are associated with difficult collophanite separation. The selection and utilization of foam-controlled collectors, efficient dispersing inhibitors, and classified desliming process will be necessary for improving flotation index in the future.

Author Contributions: Conceptualization, W.X., Y.C. and G.M.; methodology, W.X., B.S., Y.T. and Q.C.; investigation, W.X. and Y.C.; resources, W.X.; data curation, B.S. and Y.T.; writing-original draft preparation, W.X.; writing-review and editing, G.M.; supervision, S.L.; funding acquisition, W.X. and G.M. All authors have read and agreed to the published version of the manuscript.

Funding: This research was funded by National Natural Science Foundation of China (51874221), Open Foundation of State Key Laboratory of Mineral Processing (BGRIMM-KJSKL-2021-08), and Science and Technology Program of Guizhou Province (Qiankehe support (2020) 2Y048).

Data Availability Statement: Not applicable.

Conflicts of Interest: The authors declare no conflict of interest.

\section{References}

1. Cui, R.G.; Zhang, Y.F.; Guo, J.; Guo, Z.H.; Xiao, Y.P. Development strategy of phosphate rock in China under global allocation of resources. Eng. Sci. 2019, 21, 128-132. [CrossRef]

2. Liu, X.; Li, C.X.; Luo, H.H.; Cheng, R.J.; Liu, F.Y. Selective reverse flotation of apatite from dolomite in collophanite ore using saponified gutter oil fatty acid as a collector. Int. J. Miner. Process. 2017, 165, 20-27. [CrossRef]

3. Yang, H.Y.; Xiao, J.F.; Xia, Y.; Xie, Z.J.; Tan, Q.P.; Xu, J.B.; Guo, H.Y.; He, S.; Wu, S.W. Origin of the Ediacaran Weng'an and Kaiyang phosphorite deposits in the Nanhua basin, SW China. J. Asian Earth Sci. 2019, 182, 103931. [CrossRef]

4. Wang, L.S.; Long, Z.Q.; Huang, X.W.; Yu, Y.; Cui, D.L.; Zhang, G.C. Recovery of rare earths from wet-process phosphoric acid. Hydrometallurgy 2010, 101, 41-47. [CrossRef]

5. Abouzeid, A.Z.M. Physical and thermal treatment of phosphate ores-An overview. Int. J. Miner. Process. 2008, 85, 59-84. [CrossRef]

6. Ruan, Y.Y.; He, D.S.; Chi, R.A. Review on Beneficiation Techniques and Reagents Used for Phosphate Ores. Minerals 2019, 9, 253. [CrossRef]

7. Li, W.; Gao, H.; Luo, Y.J.; Gao, J. Status, trends and suggestions of phosphorus ore resources at home and abroad. China Min. Mag. 2015, 24, 6-10.

8. Fang, F.Y.; Wang, J.M. The mineralogy characteristics of overflow product from hydrocyclone in the Yunnan phosphorite mine. Value Eng. 2019, 38, 162-166.

9. Li, H.Q.; Zhang, W.; Zheng, H.F.; Ge, W.; Weng, X.Q.; Xiao, L.B.; Jiang, X.H. Process mineralogy study of phosphate ore in Dayukou area. Ind. Miner. Process. 2019, 48, 43-45.

10. Yang, W.Q.; Fang, S.X.; Pang, J.T.; He, H.T.; Zhang, Z.Q. Determination of collophane monomer dissociation degree under different grinding fineness and its use in flotation. J. Wuhan Inst. Technol. 2014, 36, 31-34. [CrossRef]

11. Han, M. Analysis of application of technological mineralogy in mineral processing. World Nonferrous Met. 2018, 13, 242-243. [CrossRef]

12. $\mathrm{Gu}, \mathrm{Y}$. Automated scanning electron microscope based mineral liberation analysis an introduction to JKMRC/FEI mineral liberation analyser. J. Miner. Mater. Charact. Eng. 2003, 2, 33-41. [CrossRef]

13. Zhou, L.G. Process Mineralogy, 3rd ed.; Metallurgical Industry Press: Beijing, China, 2007; pp. 1-7.

14. Deng, J.; Zhang, K.C.; He, D.S.; Zhao, H.Q.; Hakkou, R.; Benzaazoua, M. Occurrence of sesquioxide in a mid-low grade collophane-sedimentary apatite ore from Guizhou, China. Minerals 2020, 10, 1038. [CrossRef]

15. Leißner, T.; Hoang, D.H.; Rudolph, M.; Heinig, T.; Bachmann, K.; Gutzmer, J.; Schuberta, H.; Peuker, U.A. A mineral liberation study of grain boundary fracture based on measurements of the surface exposure after milling. Int. J. Miner. Process. 2016, 156, 3-13. [CrossRef] 
16. Chen, G.; Zhang, Q.; Zhao, W.Q.; Zhang, W.S.; Chen, K.X. Research progress of iron and aluminum removal from phosphate rock. Min. Metall. Eng. 2012, 32, 357-361. [CrossRef]

17. Zhang, Q.; He, F.Y.; Mao, S.; Liu, J.; Chen, W.H.; Ye, J.J.; Liu, B.; Huang, X.F. Dissemination characteristics and grinding fineness of collophanite and dolomite. Ind. Miner. Process. 2010, 39, 8-10. [CrossRef]

18. Wu, Z.X.; Tao, D.P. Mineralogical analysis of collophane in Yunnan using AMICS and exploration of difficult flotation mechanisms Chin. J. Eng. 2021, 43, 503-511. [CrossRef]

19. Hoang, D.H.; Kupka, N.; Peuker, U.A.; Rudolph, M. Flotation study of fine grained carbonaceous sedimentary apatite ore -Challenges in process mineralogy and impact of hydrodynamics. Miner. Eng. 2018, 121, 196-204. [CrossRef]

20. Leistner, T.; Peuker, U.A.; Rudolph, M. How gangue particle size can affect the recovery of ultrafine and fine particles during froth flotation. Miner. Eng. 2017, 109, 1-9. [CrossRef]

21. Yu, Y.X.; Ma, L.Q.; Zhang, Z.L.; Wang, L.Y.; Yao, L.Y. Mechanism of entrainment and slime coating on coal flotation. J. China Coal Soc. 2015, 40, 652-657. [CrossRef]

22. Yao, J.; Xue, J.W.; Li, D.; Fu, Y.F.; Gong, E.P.; Yin, W.Z. Effects of fine-coarse particles interaction on flotation separation and interaction energy calculation. Part Sci. Technol. 2018, 36, 11-19. [CrossRef]

23. Yin, W.Z.; Li, D.; Luo, X.M.; Yao, J.; Sun, Q.Y. Effect and mechanism of siderite on reverse flotation of hematite. Int. J. Miner. Metall. Mater. 2016, 23, 373-379. [CrossRef]

24. Hoang, D.H.; Hassanzadeh, A.; Peuker, U.A.; Rudolph, M. Impact of flotation hydrodynamics on the optimization of fine-grained carbonaceous sedimentary apatite ore beneficiation. Powder Technol. 2019, 345, 223-233. [CrossRef]

25. Song, Z.X.; Han, J.K.; Wang, W.Z.; Zhang, R.H.; Li, X. Development and application status of flotation column technology. Met. Mine 2019, 6, 20-26. [CrossRef]

26. Fan, M.M.; Tao, D.; Honaker, R.; Luo, Z.F. Nanobubble generation and its application in froth flotation (part II): Fundamental study and theoretical analysis. Min. Sci. Technol. 2010, 20, 159-177. [CrossRef] 